\title{
Multimodality Treatment in Metastatic Gastric Cancer: From Past to Next Future
}

\author{
Alessandro Parisi ${ }^{1,2, *}$ (D) Giampiero Porzio ${ }^{1,2}$ and Corrado Ficorella ${ }^{1,2}$ \\ 1 Medical Oncology, St. Salvatore Hospital, University of L'Aquila, 67100 L'Aquila, Italy; \\ porzio.giampiero@gmail.com (G.P.); corrado.ficorella@univaq.it (C.F.) \\ 2 Department of Biotechnology and Applied Clinical Sciences, University of L'Aquila, 67100 L'Aquila, Italy \\ * Correspondence: alexparis@hotmail.it; Tel.: +39-086-236-8709; Fax: +39-086-236-8682
}

Received: 24 July 2020; Accepted: 9 September 2020; Published: 11 September 2020

Simple Summary: Gastric cancer remains an incurable disease in most of the cases. Anyway, the progress achieved over the last decade in terms of knowledge of its biology and available therapeutic options, together with a greater attention to the concept of supportive care, led to a progressive and incremental survival benefit in metastatic gastric cancer patients. In this review we summarize the current standard management and the major completed or ongoing clinical trials involving systemic, surgical or locoregional treatment of metastatic gastric cancer along with emerging concepts likely to improve patients' outcome in the next future.

\begin{abstract}
Gastric cancer (GC) still remains an incurable disease in almost two-thirds of the cases. However, a deeper knowledge of its biology in the last few years has revealed potential biomarkers suitable for tailored treatment with targeted agents. This aspect, together with the improvement in early supportive care and a wiser use of the available cytotoxic drugs across multiple lines of treatment, has resulted in incremental and progressive survival benefits. Furthermore, slowly but surely, targeted therapies and immune checkpoint inhibitors are revising the therapeutic scenario even in metastatic GC and especially in particular subgroups. Moreover, important study results regarding the possible role of an integrated approach combining systemic, surgical, and locoregional treatment in carefully selected oligometastatic GC patients are awaited. This review summarizes the state-of-the-art and the major ongoing trials involving a multimodal treatment of metastatic GC.
\end{abstract}

Keywords: advanced gastric cancer; chemotherapy; targeted therapy; immunotherapy; surgical treatment; supportive care; locoregional treatment

\section{Introduction}

Gastric cancer (GC) is the fifth malignancy and the third cause of cancer death worldwide, according to the global cancer statistics presented in 2018 (GLOBOCAN 2018 [1]). Despite the improvements in the perioperative treatment, about $50 \%$ of resected patients with curative intent eventually relapse, while $80 \%$ of patients present a de novo unresectable or metastatic disease [2]. In this setting, fluoropyrimidine- and platinum-based systemic treatment represents the standard of care, with median overall survival (mOS) of about 10 months in human epidermal receptor 2 (HER-2) negative disease [3], extending to about 15 months in HER-2 positive disease with the addition of the monoclonal antibody $(\mathrm{mAb})$ trastuzumab [4]. After almost a decade of plateau in survival in metastatic GC (mGC), the advent of vascular endothelial growth factor receptor-2 (VEGFR-2) inhibitors such as ramucirumab [5,6] and apatinib [7], as well as the innovative oral cytotoxic trifluridine-tipiracil [8] and, especially in particular subgroups of patients (i.e., programmed death [PD] ligand 1 [PD-L1] positive, microsatellite instability [MSI]-high, Epstein-Barr virus [EBV], positive or high tumor 
mutational burden [TMB]), immune checkpoint inhibitors (ICIs) $[9,10]$ led to progressive incremental survival advantages.

On the other hand, if surgery represents the cornerstone in the curative setting, its role in the metastatic disease is associated with controversial results [11-14] as well as the impact of other locoregional strategies [15-19]. In this regard, the concept of "oligometastatic" GC, stating a disease characterized by limited tumor burden (i.e., M1 with retroperitoneal lymph nodes and/or one potentially resectable incurable site), is taking place as emerging clinical entity, distinct from extensively mGC (M1 patients other than oligometastatic) in terms of both treatment plan (multimodal treatment vs. systemic treatment alone, respectively) and survival (mOS of about 31 months vs. 9-11 months, respectively) [12-15,20].

Furthermore, a growing amount of evidence highlighted the importance of the best supportive care (BSC), especially in such cancer patients at high risk of malnutrition, loss of body composition parameters, and sarcopenia, with detrimental effects on safety and outcome of both systemic and surgical treatments [21-23].

In this article, we review the major advances in systemic, surgical, and locoregional treatment of mGC in parallel with the evolution of the role of BSC in this disease.

\section{Systemic Treatment}

\subsection{Standard of Care}

\subsubsection{First-Line Treatment}

The issue regarding type and intensity of the first-line treatment in $\mathrm{mGC}$ has long been debated and investigated. A combination chemotherapy demonstrated to improve survival and quality of life (QoL) compared to single-agent fluoropyrimidine [3].

In HER-2 negative patients, platinum/fluoropyrimidine doublet chemotherapy is the preferred regimen both in Western and Eastern countries, reaching a mOS of about 10 months, with cisplatin and 5-fluorouracil (5-FU) replaceable by oxaliplatin and capecitabine, respectively, according to their non-inferiority and better safety profile [24]. Irinotecan/5-FU combinations represent a further valuable first-line alternative, resulting in at least non-inferior as efficacy and with a better safety profile if compared to a platinum/fluoropyrimidine regimen with or without epirubicin [25].

In HER-2 positive disease (15-20\% of the cases), according to the results of the randomized phase III TOGA trial, adding the anti-HER2 monoclonal antibody trastuzumab to a fluoropyrimidine/cisplatin doublet has shown to improve the overall response rate (ORR) $(47 \%$ vs. $35 \%, p=0.0017)$, progression-free survival (PFS) (6.7 vs. 5.5 months, $\mathrm{HR}=0.71, p=0.0002)$, and OS (13.8 vs. 11.1 months, $\mathrm{HR}=0.74$, $p=0.0046$ ) [4], with the greatest benefit in OS in favor of the strong (3+) HER-2 overexpressing tumors (16 vs. 11.8 months, $\mathrm{HR}=0.65, p=0.0046$ ).

The role of adding a third cytotoxic agent to a doublet with platinum/fluoropyrimidine as first-line treatment of mGC has been widely investigated and if the advantage of epirubicin is still controversial [26], several docetaxel-based triplet regimens have been developed. In general, with respect to a doublet, a triplet regimen allows higher ORR (RR: 1.25, 95\%CI 1.09-1.44) at the price of major incidence of adverse events (AEs), particularly severe mucositis $(9.7 \%$ vs. $4.7 \%)$, thrombocytopenia ( $6.2 \%$ vs. $3.8 \%)$, and infection ( $10.2 \%$ vs. $6.4 \%)$, leading to a statistically significant but clinically very low relevant gain in both PFS (HR $=0.8,95 \% \mathrm{CI} 0.69-0.93)$ and OS (HR $=0.90$, 95\%CI 0.83-0.97) [27]. Variants of the standard DCF regimen, combination of docetaxel, cisplatin, and fluorouracil first tested in the V325 phase III trial [28], as dose-modified DCF (mDCF) [29] or even non cisplatin-containing regimens such as FLOT [20], TEF [30], or similar [31] (combinations of docetaxel, oxaliplatin, and fluoropyrimidine) showed a more favorable toxicity profile. A Western phase III study is currently comparing TFOX (similar to the TEF regimen) with FOLFOX as first-line treatment in mGC (GASTFOX: NCT03006432), while an Eastern phase III study is investigating in the 
same setting, the role of a triplet combination of irinotecan, fluorouracil, and oxaliplatin [NCT04358354], as already tested in metastatic colorectal cancer (mCRC) [32,33].

To date, it is crucial to select the patient fit for an intensive regimen and features of both patient (age, comorbidities, expected QoL) and disease (tumor burden, symptoms) play a central role in the decision-making process [31]. Therefore, a triplet chemotherapy, can be justified in those patients less likely to receive second-line treatment, with high tumor burden and symptomatic disease needing rapid tumor shrinkage, with careful management of the toxicity profile. On the other hand, a sequential strategy should be preferred in those patients with low tumor burden and asymptomatic disease, in favor of a better QoL profile and a reduced risk of cross-resistance in view of a potential taxane-based second-line treatment.

\subsubsection{Second- and Further Line Treatment}

Indeed, for mGC patients progressed to a first-line treatment and maintaining acceptable performance status, the human monoclonal antibody $(\mathrm{mAb})$ anti-VEGFR2 ramucirumab has been shown to improve OS both alone if compared to BSC (5.2 vs. 3.8 months, HR =0.77, $p=0.047$ ) and combined with paclitaxel with respect to paclitaxel alone (9.6 vs. 7.4 months, $\mathrm{HR}=0.80, p=0.017$ ), as second-line treatment as the result of two international randomized double-blind phase III trials (REGARD and RAINBOW, respectively) [5,6]. Both efficacy and safety data of ramucirumab have been confirmed in "real-life" settings [34,35].

Besides ramucirumab, single-agent taxane (paclitaxel and docetaxel) and irinotecan showed increased survival compared to BSC as second-line treatment in mGC with a median survival gain ranging from 1.4 to 2.7 months among individual studies and with different safety profiles [36-38].

Notable, a doublet chemotherapy taxane/irinotecan plus platinum and fluoropyrimidine provides no gain in survival if compared to taxane/irinotecan monotherapy as second-line treatment in mGC and is associated with increased toxicity [39].

Regarding third-line treatment in $\mathrm{MGC}$, the first prospective evidence supporting the role of a systemic therapy in this setting came from a randomized phase III trial comparing the VEGFR-2 tyrosine kinase inhibitor (TKI) apatinib over placebo, (mOS 6.5 vs. 4.8 months, respectively, $\mathrm{HR}=0.70$, $p=0.149$ ) in Eastern mGC patients pretreated with two or more lines of chemotherapy [7]. Regrettably, these results were not confirmed in the same clinical setting in Eastern populations in the phase III ANGEL trial [40].

Then, another two randomized phase III trials showed a statistically significant improvement in OS and QoL for the novel oral cytotoxic trifluridine/tipiracil over placebo (5.7 vs. 3.6 months, HR $=0.69$, $p=0.0005$ ) in a global population [8] and for the anti-PD1 agent nivolumab over placebo in Eastern patients [9]. Furthermore, according to the results of the phase II KEYNOTE 059 study [41], the Food and Drug Administration (FDA) in the USA approved pembrolizumab in mGC patients with combined positive score (CPS) for PD-L1 $\geq 1 \%$ and/or MSI-high tumors.

\subsection{Targeted Agents}

GC frequently harbors genetic aberrations and genomic instability as amplifications and co-amplifications of genes encoding for receptor tyrosine kinases (RTKs) (RAS, HER-2, and MET), for cell cycle mediators (such as proteins related to DNA damage repair) or even interspersed among pathways related to angiogenesis, all molecular hallmarks of GC involved in tumor initiation, progression, and treatment resistance [2].

However, with the exception of trastuzumab and ramucirumab in the first- and second-line setting respectively, drug development in targeted agents provided disappointing results in mGC phase III clinical trials targeting HER-2 with TKI [42,43], antibody-drug conjugate (ADC) [44], or dual-blockade [45], EGFR [46,47], MET [48,49], PI3K/mTOR [50,51], STAT3 [52], MMP9 [53], and PARP [54] (Table 1). 
This failure is assumed to be caused by the highly heterogeneous both intra- and interpatient histologic features and molecular biology of GC as recently highlighted by The Cancer Genome Atlas (TCGA) classification [55], and therefore by the lack of a proper biomarker selection. One solution to overcome the obstacle of the intratumor heterogeneity may be the use of circulating tumor DNA (ctDNA) to detect aberrations of genomic instability not detecting by tumor sampling and analysis [56,57]. Indeed, for example, a small subset of mGC seems to be mainly driven by the oncogenic EGFR pathway and anti-EGFR treatment with cetuximab may result in a relevant clinical benefit in heavily pretreated patients [58].

Intriguingly, in contrast with the positive results reached in the second-line, ramucirumab did not improve OS as first-line treatment [58] and the monoclonal antibody targeting VEGF-A bevacizumab failed to improve OS in the same setting [50-60]. These discrepancies between colorectal cancer (CRC), in which angiogenic inhibition is a SOC treatment both in the first- and second-line setting [61], and GC may be related to deep differences in biology, including tumor microenvironment and molecular pathways of resistance to VEGF inhibition (stromal signaling pathways related to FGF, PIGF, and PDGF and oncogenic signaling pathways related to RAF, RET, and cKIT) [2,55,56].

On the other hand, the VEGFR-2 TKI apatinib improved OS as third-line treatment in the Eastern population [7] but failed in the same setting in Western patients [40] (Table 2). These results may be at least in part explainable with differences in both prognostic factors and biological profiles between the two populations [2,55].

Ongoing phase III trials with the VEGFR1-2-3 TKI fruquintinib (FRUTIGA: NCT02773524) and the multi-TKI regorafenib (INTEGRATE II: NCT02773524) are assessing the value of a deeper both angiogenic, stromal, and oncogenic inhibition in $\mathrm{mGC}$, but to date, further studies are warranted to identify potential molecular biomarkers for selecting mGC patients who should benefit most from the addition of VEGF inhibitors.

Regarding HER-2 targeted therapy, with the exception of the significant OS benefit provided by the addition of trastuzumab to chemotherapy in the first-line setting [4], the HER-1 TKI lapatinib, the HER-2 dual-blockade with pertuzumab and trastuzumab or the ADC trastuzumab emtansine (T-DM1) led to negative results in different line settings and combinations in HER-2 positive mGC [41-44] (Table 1).

Notably, in the randomized phase II DESTINY-Gastric01 trial, presented at the 2020 ASCO Virtual Meeting, the ADC trastuzumab deruxtecan (DS-8201a) provided a significant improvement in both ORR ( $51 \%$ vs. $14 \%, p<0.001)$ and OS (12.5 vs. 8.4 months, $p=0.01)$ compared to physician's choice chemotherapy in heavily pretreated HER-2 positive Eastern mGC patients, with myelosuppression and interstitial lung disease as notable toxic effects [62]. Data from the Western population (DESTINY-Gastric02: NCT04014075) and confirming phase III trials are awaited.

Among other interesting targeted agents, as proof of the importance of a proper molecular selection, the tight junction protein claudin 18.2 (CLDN18.2) inhibitor zolbetuximab showed improved PFS and OS in association with chemotherapy as first-line treatment of CLDN18.2-positive mGC in a phase II trial [63]. Two phase III confirmatory trials are currently ongoing (SPOTLIGHT: NCT03504397 and GLOW: NCT035653507) (Table 1). 
Table 1. List of completed/ongoing phase III or II/III trials with targeted agents in metastatic gastric cancer.

\begin{tabular}{|c|c|c|c|c|c|c|c|c|c|c|c|c|}
\hline $\begin{array}{l}\text { Study name } \\
\text { [reference] }\end{array}$ & Year & Country & $\mathrm{Ph}$ & Line & $\mathbf{N}$ & Target & Drug & $\begin{array}{l}\text { Selected } \\
\text { Population }\end{array}$ & $\begin{array}{l}\text { Study Intervention } \\
\text { exp/cont }\end{array}$ & $\begin{array}{l}\text { OS-PFS } \\
\text { (months) } \\
\text { exp/cont }\end{array}$ & $\begin{array}{l}\text { Grade 3-4 AEs } \\
\quad \exp (\%)\end{array}$ & Res \\
\hline ToGA [4] & 2010 & Inter & III & $1^{\circ}$ & 594 & HER2 & Trastuzumab & $\begin{array}{c}\text { HER2 pos } \\
\text { (IHC3+, FISH+) }\end{array}$ & $\begin{array}{c}\mathrm{FP}(\mathrm{XP})+ \\
\text { trastuzumab } \\
\mathrm{FP}(\mathrm{XP})\end{array}$ & $\begin{array}{l}13.8-6.7 \\
11.1-5.5\end{array}$ & $\begin{array}{c}\text { nausea (67) } \\
\text { vomiting (50) } \\
\text { neutropenia (53) }\end{array}$ & Pos \\
\hline TRIO-013/LOGiC [42] & 2016 & Inter & III & $1^{\circ}$ & 545 & HER1-2 & Lapatinib & $\begin{array}{l}\text { HER2 pos } \\
\text { (FISH+) }\end{array}$ & $\begin{array}{c}\text { XELOX + lapatinib } \\
\text { XELOX + PBO }\end{array}$ & $\begin{array}{l}12.2-6.0 \\
10.5-5.4\end{array}$ & $\begin{array}{c}\text { diarrhea (12) } \\
\text { nausea (6) } \\
\text { vomiting (6) }\end{array}$ & Neg \\
\hline TyTAN [43] & 2014 & Asia & III & $2^{\circ}$ & 261 & HER1-2 & Lapatinib & $\begin{array}{l}\text { HER2 pos } \\
(\text { FISH+) }\end{array}$ & $\begin{array}{l}\text { PTX + lapatinib } \\
\text { PTX }\end{array}$ & $\begin{array}{c}11.0-5.5 \\
8.9-4.4\end{array}$ & $\begin{array}{c}\text { diarrhea (18) } \\
\text { neutropenia (31) } \\
\text { leukopenia (24) }\end{array}$ & Neg \\
\hline GATSBY [44] & 2017 & Inter & II-III & $2^{\circ}$ & 345 & HER2 & T-DM1 & $\begin{array}{c}\text { HER2 pos } \\
\text { (IHC3+, } \\
\text { IHC2+/FISH+) }\end{array}$ & $\begin{array}{c}\text { T-DM1 } \\
\text { DTX or PTX }\end{array}$ & $\begin{array}{l}7.9-2.7 \\
8.2-2.9\end{array}$ & $\begin{array}{c}\text { Anemia (26) } \\
\text { thrombocytopenia } \\
\text { (11) }\end{array}$ & Neg \\
\hline JACOB [45] & 2018 & Inter & III & $1^{\circ}$ & 780 & HER2 & Pertuzumab & $\begin{array}{c}\text { HER2 pos } \\
\text { (IHC3+, } \\
\text { IHC2+/FISH+) }\end{array}$ & $\begin{array}{c}\mathrm{FP}(\mathrm{XP})+\text { trast- } \\
\text { pertuzumab } \\
\mathrm{FP}(\mathrm{XP})+\text { trast-PBO }\end{array}$ & $\begin{array}{l}17.5-8.5 \\
14.2-7.0\end{array}$ & $\begin{array}{c}\text { neutropenia (30) } \\
\text { anemia (15) } \\
\text { diarrhea (13) }\end{array}$ & Neg \\
\hline $\begin{array}{l}\text { ASLAN001-012 } \\
\text { (NCT03130790 }\end{array}$ & Ongoing & Asia & II-III & $1^{\circ}$ & 400 & HER1-2-3 & Varlitinib & $\begin{array}{c}\text { HER1-2 } \\
\text { co-expression }\end{array}$ & $\begin{array}{c}\text { mFOLFOX }+ \\
\text { varlitinib mFOLFOX } \\
+ \text { PBO }\end{array}$ & OS (PE) & NA & NA \\
\hline EXPAND [46] & 2013 & Inter & III & $1^{\circ}$ & 904 & HER1 & Cetuximab & All comers & $\begin{array}{c}\mathrm{XP}+\underset{\mathrm{XP}}{\text { Cetuximab }} \\
\end{array}$ & $\begin{array}{c}9.4-4.4 \\
10.7-5.6\end{array}$ & $\begin{array}{c}\text { Neutropenia (22) } \\
\text { hypokalaemia } \\
(13) \\
\text { hypomagnesaemia } \\
(10 \%)\end{array}$ & $\mathrm{Neg}$ \\
\hline REAL3 [47] & 2013 & UK & III & $1^{\circ}$ & 553 & HER1 & Panitumumab & All comers & $\begin{array}{c}\text { mEOC }+ \\
\text { Panitumumab } \\
\text { EOC }\end{array}$ & $\begin{array}{c}8.8-6.0 \\
11.3-7.4\end{array}$ & $\begin{array}{l}\text { Vomiting (9) } \\
\text { diarrhea (17) } \\
\text { Lethargy (17) }\end{array}$ & Neg \\
\hline RILOMET-1 [48] & 2017 & West & III & $1^{\circ}$ & 609 & HGF & Rilotumumab & $\begin{array}{l}\text { MET pos } \\
\text { HER2 neg }\end{array}$ & $\begin{array}{c}\text { ECX + Rilotumumab } \\
\text { ECX + PBO }\end{array}$ & $\begin{array}{c}8.8-5.6 \\
10.7-6.0\end{array}$ & $\begin{array}{l}\text { Neutropenia (29) } \\
\text { anaemia (12) } \\
\text { fatigue (10) }\end{array}$ & Neg \\
\hline
\end{tabular}


Table 1. Cont

\begin{tabular}{|c|c|c|c|c|c|c|c|c|c|c|c|c|}
\hline $\begin{array}{l}\text { Study name } \\
\text { [reference] }\end{array}$ & Year & Country & $\mathbf{P h}$ & Line & $\mathbf{N}$ & Target & Drug & $\begin{array}{l}\text { Selected } \\
\text { Population }\end{array}$ & $\begin{array}{c}\text { Study Intervention } \\
\text { exp/cont }\end{array}$ & $\begin{array}{l}\text { OS-PFS } \\
\text { (months) } \\
\text { exp/cont }\end{array}$ & $\begin{array}{l}\text { Grade 3-4 AEs } \\
\quad \exp (\%)\end{array}$ & Res \\
\hline METGastric [49] & 2017 & Inter & III & $1^{\circ}$ & 562 & MET & Onartuzumab & $\begin{array}{l}\text { MET pos HER2 } \\
\text { neg }\end{array}$ & $\begin{array}{c}\text { mFOLFOX6 + } \\
\text { Onartuzumab } \\
\text { mFOLFOX6 + PBO }\end{array}$ & $\begin{array}{l}11.3-6.8 \\
11.0-6.7\end{array}$ & $\begin{array}{l}\text { Neutropenia (35) } \\
\text { hypoalbuminemia } \\
\text { (6) pulmonary } \\
\text { embolism (6) }\end{array}$ & $\mathrm{Neg}$ \\
\hline FIGHT (NCT03694522) & 2017 & Inter & III & $1^{\circ}$ & 548 & FGFR2 & Bemarituzumab & $\begin{array}{c}\text { FGFR2 } \\
\text { overexp/amp } \\
\text { HER2 neg }\end{array}$ & $\begin{array}{c}\text { mFOLFOX6 + } \\
\text { Bemarituzumab } \\
\text { mFOLFOX6 + PBO }\end{array}$ & OS (PE) & NA & NA \\
\hline GRANITE-1 [50] & 2013 & Inter & III & $2^{\circ}-3^{\circ}$ & 656 & mTOR & Everolimus & All comers & $\begin{array}{c}\text { everolimus + BSC } \\
\text { PBO + BSC }\end{array}$ & $\begin{array}{l}5.4-1.7 \\
4.3-1.4\end{array}$ & $\begin{array}{c}\text { Anemia (16) } \\
\text { anorexia (11) } \\
\text { fatigue (8) }\end{array}$ & Neg \\
\hline RADPAC [51] & 2017 & Germany & III & $2^{\circ}-4^{\circ}$ & 300 & mTOR & Everolimus & All comers & $\begin{array}{l}\text { PTX + everolimus } \\
\text { PTX + PBO }\end{array}$ & $\begin{array}{l}6.1-2.2 \\
5.0-2.0\end{array}$ & $\begin{array}{l}\text { Anemia (13) } \\
\text { mucositis (13) } \\
\text { diarrhea (8) }\end{array}$ & $\mathrm{Neg}$ \\
\hline GOLD [54] & 2017 & Asia & III & $3^{\circ}$ & 525 & PARP & Olaparib & All comers & $\begin{array}{l}\text { PTX + olaparib } \\
\text { PTX + PBO }\end{array}$ & $\begin{array}{l}8.8- \\
6.9-\end{array}$ & $\begin{array}{c}\text { Neutropenia (30) } \\
\text { leucopenia (10) }\end{array}$ & $\mathrm{Neg}$ \\
\hline $\begin{array}{l}\text { PARALLEL } 303 \\
\text { (NCT03427814) }\end{array}$ & Ongoing & Inter & III & $1^{\circ}$ & 540 & PARP & Pamiparib & All comers & $\begin{array}{c}\text { Pamiparib } \\
\text { maintenance } \\
\text { PBO maintenance }\end{array}$ & PFS (PE) & NA & NA \\
\hline BRIGHTER [52] & 2018 & Inter & III & $2^{\circ}$ & 714 & STAT3 & Napabucasin & All comers & $\begin{array}{c}\text { PTX + napabucasin } \\
\text { PTX + PBO }\end{array}$ & $\begin{array}{l}6.9-3.5 \\
7.3-3.6\end{array}$ & Diarrhea (16) & $\mathrm{Neg}$ \\
\hline GAMMA-1 [53] & 2019 & West & III & $1^{\circ}$ & 432 & MMP9 & Andecaliximab & HER2 neg & $\begin{array}{c}\text { mFOLFOX6 + } \\
\text { Andecaliximab } \\
\text { mFOLFOX6 + PBO }\end{array}$ & $\begin{array}{l}12.5-7.5 \\
11.8-7.1\end{array}$ & $\begin{array}{c}\text { Nausea (NA) } \\
\text { diarrhea (NA) } \\
\text { fatigue (NA) } \\
\text { neutropenia (NA) }\end{array}$ & $\mathrm{Neg}$ \\
\hline $\begin{array}{c}\text { SPOTLIGHT } \\
\text { (NCT03504397) }\end{array}$ & Ongoing & Inter & III & $1^{\circ}$ & 550 & $\begin{array}{c}\text { Claudin } \\
18.2\end{array}$ & Zolbetuximab & $\begin{array}{l}\text { CLDN18.2 pos } \\
\text { HER2 neg }\end{array}$ & $\begin{array}{l}\text { mFOLFOX6 + } \\
\text { Zolbetuximab } \\
\text { XELOX + PBO }\end{array}$ & PFS (PE) & NA & NA \\
\hline
\end{tabular}


Table 1. Cont

\begin{tabular}{|c|c|c|c|c|c|c|c|c|c|c|c|c|}
\hline $\begin{array}{l}\text { Study name } \\
\text { [reference] }\end{array}$ & Year & Country & $\mathrm{Ph}$ & Line & $\mathbf{N}$ & Target & Drug & $\begin{array}{l}\text { Selected } \\
\text { Population }\end{array}$ & $\begin{array}{l}\text { Study Intervention } \\
\text { exp/cont }\end{array}$ & $\begin{array}{c}\text { OS-PFS } \\
\text { (months) } \\
\text { exp/cont }\end{array}$ & $\begin{array}{l}\text { Grade 3-4 AEs } \\
\quad \exp (\%)\end{array}$ & Res \\
\hline $\begin{array}{c}\text { GLOW } \\
\text { (NCT035653507) }\end{array}$ & Ongoing & Inter & III & $1^{\circ}$ & 500 & $\begin{array}{c}\text { Claudin } \\
18.2\end{array}$ & Zolbetuximab & $\begin{array}{l}\text { CLDN18.2 pos } \\
\text { HER2 neg }\end{array}$ & $\begin{array}{c}\text { XELOX + } \\
\text { Zolbetuximab } \\
\text { mFOLFOX6 + PBO }\end{array}$ & PFS (PE) & NA & NA \\
\hline AVAGAST [60] & 2011 & Inter & III & $1^{\circ}$ & 774 & VEGFA & Bevacizumab & All comers & $\begin{array}{c}\mathrm{FP}(\mathrm{XP})+ \\
\text { Bevacizumab } \\
\mathrm{FP}(\mathrm{XP})+\mathrm{PBO}\end{array}$ & $\begin{array}{l}12.1-6.7 \\
10.1-5.3\end{array}$ & $\begin{array}{l}\text { Neutropenia (35) } \\
\text { anemia (10) } \\
\text { anorexia (8) }\end{array}$ & Neg \\
\hline AVATAR [59] & 2015 & Inter & III & $1^{\circ}$ & 202 & VEGFA & Bevacizumab & All comers & $\begin{array}{c}\mathrm{XP}+\text { Bevacizumab } \\
\mathrm{XP}+\mathrm{PBO}\end{array}$ & $\begin{array}{l}11.4-6-0 \\
10.5-6.3\end{array}$ & $\begin{array}{c}\text { Vomiting (22) } \\
\text { neutropenia (14) } \\
\text { hypertension (10) }\end{array}$ & $\mathrm{Neg}$ \\
\hline REGARD [5] & 2014 & Inter & III & $2^{\circ}$ & 355 & VEGFR2 & Ramucirumab & All comers & $\begin{array}{c}\text { Ramucizumab + PBO } \\
\text { PBO }\end{array}$ & $\begin{array}{l}5.2-2.1 \\
3.8-1.3\end{array}$ & $\begin{array}{c}\text { Fatigue (6) } \\
\text { hypertension (8) }\end{array}$ & Pos \\
\hline RAINBOW [6] & 2014 & Inter & III & $2^{\circ}$ & 665 & VEGFR2 & Ramucirumab & All comers & $\begin{array}{c}\text { PTX + Ramucizumab } \\
\text { PTX + PBO }\end{array}$ & $\begin{array}{l}9.6-4-4 \\
7.4-2.9\end{array}$ & $\begin{array}{c}\text { fatigue (12) } \\
\text { neuropathy (8) } \\
\text { neutropenia (22) } \\
\text { hypertension (14) }\end{array}$ & Pos \\
\hline RAINFALL [58] & 2019 & Inter & III & $1^{\circ}$ & 645 & VEGFR2 & Ramucirumab & HER2 neg & $\begin{array}{c}\mathrm{FP}(\mathrm{XP})+ \\
\text { Ramucirumab } \\
\mathrm{FP}(\mathrm{XP})+\mathrm{PBO}\end{array}$ & $\begin{array}{l}11.2-5-7 \\
10.7-5.4\end{array}$ & $\begin{array}{l}\text { Neutropenia (26) } \\
\text { anemia (12) } \\
\text { hypertension (10) }\end{array}$ & $\mathrm{Neg}$ \\
\hline $\begin{array}{c}\text { RAMIRIS } \\
\text { (NCT03081143) }\end{array}$ & Ongoing & Germany & II-III & $2^{\circ}$ & 429 & VEGFR2 & Ramucirumab & All comers & $\begin{array}{c}\text { FOLFIRI + } \\
\text { Ramucirumab } \\
\text { PTX + Ramucirumab }\end{array}$ & $\begin{array}{l}\text { OS/ORR } \\
\text { (PE) }\end{array}$ & NA & NA \\
\hline $\begin{array}{c}\text { ARMANI } \\
\text { (NCT02934464) }\end{array}$ & Ongoing & Italy & III & $1^{\circ}$ & 280 & VEGFR2 & Ramucirumab & HER2 neg & $\begin{array}{c}\text { PTX + Ramucirumab } \\
\text { (switch maintenance) } \\
\text { FOLFOX4, FOLFOX6, } \\
\text { XELOX }\end{array}$ & PFS (PE) & NA & NA \\
\hline RINDBeRG & Ongoing & Japan & III & $3^{\circ}$ & 400 & VEGFR2 & Ramucirumab & All comers & $\begin{array}{c}\text { IRI + Ramucirumab } \\
\text { (beyond PD) } \\
\text { IRI }\end{array}$ & OS (PE) & NA & NA \\
\hline
\end{tabular}


Table 1. Cont.

\begin{tabular}{|c|c|c|c|c|c|c|c|c|c|c|c|c|}
\hline $\begin{array}{l}\text { Study name } \\
\text { [reference] }\end{array}$ & Year & Country & $\mathrm{Ph}$ & Line & $\mathbf{N}$ & Target & Drug & $\begin{array}{l}\text { Selected } \\
\text { Population }\end{array}$ & $\begin{array}{c}\text { Study Intervention } \\
\text { exp/cont }\end{array}$ & $\begin{array}{c}\text { OS-PFS } \\
\text { (months) } \\
\text { exp/cont }\end{array}$ & $\begin{array}{l}\text { Grade 3-4 AEs } \\
\quad \exp (\%)\end{array}$ & Res \\
\hline $\begin{array}{c}\text { HENGRUI } 20101208 \\
\text { [7] }\end{array}$ & 2016 & China & III & $\geq 3^{\circ}$ & 267 & VEGFR2 & Apatinib & All comers & $\begin{array}{l}\text { Apatinib } \\
\text { PBO }\end{array}$ & $\begin{array}{l}6.5-2.6 \\
4.7-1.8\end{array}$ & $\begin{array}{c}\text { HFS (8.5) } \\
\text { hypertension } \\
(4.5)\end{array}$ & Pos \\
\hline ANGEL [40] & 2019 & Inter & III & $\geq 3^{\circ}$ & 460 & VEGFR2 & Apatinib & All comers & $\begin{array}{c}\text { Apatinib + BSC } \\
\text { PBO + BSC }\end{array}$ & $\begin{array}{c}5.7-2.8 \\
5.1-1.7\end{array}$ & $\begin{array}{c}\text { Hypertension (34) } \\
\text { HFS (26) }\end{array}$ & $\mathrm{Neg}$ \\
\hline $\begin{array}{c}\text { TJCC006 } \\
\text { (NCT03598348) }\end{array}$ & Ongoing & China & III & $1^{\circ}$ & 288 & VEGFR2 & Apatinib & HER2 neg & $\begin{array}{c}\text { Apatinib }+X \\
\text { maintenance after } \\
\text { XELOX } \\
\text { Apatinib } \\
\text { maintenance after } \\
\text { XELOX } \\
\text { observation after } \\
\text { XELOX }\end{array}$ & PFS (PE) & NA & NA \\
\hline $\begin{array}{c}\text { FRUTIGA } \\
\text { (NCT02773524) }\end{array}$ & Ongoing & Inter & III & $2^{\circ}$ & 544 & VEGFR1/2/3 & Fruquintinib & All comers & $\begin{array}{c}\text { PTX + Fruquintinib } \\
\text { PTX + PBO }\end{array}$ & OS (PE) & NA & NA \\
\hline $\begin{array}{l}\text { INTEGRATE II } \\
\text { (NCT02773524) }\end{array}$ & Ongoing & Inter & III & $\geq 3^{\circ}$ & 350 & Multi-target & Regorafenib & All comers & $\begin{array}{c}\text { Regorafenib } \\
\text { PBO }\end{array}$ & OS (PE) & NA & NA \\
\hline
\end{tabular}

Ph: phase; OS: overall survival; PFS: progression-free survival; Exp: experimental arm; Cont: control arm; Res: study results according to the primary endpoint; PE: primary endpoint of the study; NA: not available; pos: positive; neg: negative; Inter: international/global; West: Western countries; HFS: hand-foot syndrome; Trast: trastuzumab; overexp: overexpression; amp: amplification; FP: 5-fluorouracil + cisplatin; XP: capecitabine-cisplatin; XELOX: capecitabine + oxaliplatin; PBO: placebo; BSC: best supportive care; PTX: paclitaxel; DTX: docetaxel; ECX: epirubicin + cisplatin + capecitabine; mEOC: modified-EOC (epirubicin + oxaliplatin + capecitabine); mFOLFOX6: modified FOLFOX6 (5-fluorouracil + leucovorin + oxaliplatin); PE: primary endpoint; CT: chemotherapy. 


\subsection{Immunotherapy}

Breakthrough results from immune checkpoint inhibitors (ICI) have recently opened the doors to a new era of cancer immunotherapy, leading to a paradigm shift in cancer treatment [64]. Particularly, GC seems to be an "immunologically hot" tumor, associated with overexpression of immune checkpoint proteins (such as PD-L1, in up to $65 \%$ of the GCs), high TMB (i.e., the total number of mutations per coding area of a tumor genome), and immune system evasion, providing the rationale for immunotherapy with PD-1/PD-L1 inhibitors, alone or combined with chemotherapy or targeted agents [65].

In the landmark phase III ATTRACTION-02 trial [9], the human mAb anti-PD1 nivolumab significantly prolonged OS over placebo (5.2 vs. 4.1 months, $\mathrm{HR}=0.63, p<0.0001$ ) in Asian mGC patients progressed to almost two previous regimens, reaching a 3-year OS of $5.6 \%$ and $1.9 \%$, respectively, suggesting that a proportion of $\mathrm{mGC}$ patients achieved durable OS benefit from nivolumab. The toxicity profile was manageable with mainly mild to moderate AEs including diarrhea, fatigue, pruritus, and rash. Of note, a longer OS was observed in those patients who experienced treatment-related AEs of special interest (endocrine, gastrointestinal, hepatic, hypersensitivity reaction, pulmonary, renal, or skin) compared with those who did not (2-year OS of $20 \%$ and $0 \%$, respectively) [66]. This is in line with previous reports in other cancer settings [67]. Intriguingly, no difference was seen according to PD-L1 status (measured with the tumor proportion score [TPS]) even if PD-L1 immunohistochemistry threshold for positivity was set at $1 \%$ and tumor samples were available in only about $40 \%$ of patients.

Similar data were obtained in Western populations even if phase III data are lacking. The phase I-II CheckMate-032 trial tested nivolumab alone or combined with the fully human mAb inhibitor of cytotoxic T-lymphocyte associated protein-4 (CTLA-4) ipilimumab in 160 heavily pretreated mGC patients, reaching ORR of $12 \%$ and $24 \%$ and G3-4 AEs of 17 and $47 \%$, respectively [68]. Intriguingly, these activity results were obtained regardless of PD-L1 status. The ongoing phase III CheckMate-649 trial (NCT02872116) is testing this association as fist-line treatment of HER2-negative mGC (Table 2).

On the other hand, the human mAb anti-PD1 pembrolizumab was first globally tested in the large phase II KEYNOTE-059 trial, reaching higher ORR (15.5\% vs. $6.4 \%)$ and longer duration of response (DOR, 16.3 vs. 6.9 months) in PD-L1-positive (defined as combined positive score [CPS] $\geq 1 \%$ ) than in PD-L1-negative mGC as third- or further-line treatment [41]. Even then, phase III study data are awaited (Table 2).

At least in part in line with these data, encouraging results were found in phase III trials evaluating the efficacy of monotherapy with PD-1/PD-L1 inhibitors compared with chemotherapy. In a recent 2-year update analysis of the KEYNOTE-061 trial, pembrolizumab monotherapy provided a trend toward improved OS as second-line treatment in mostly Western PD-L1-positive (CPS $\geq 1 \%$ ) mGC compared to paclitaxel (mOS 9.1 vs. 8.3 months, $\mathrm{HR}=0.81, p=0.03$ ) [69]. An even more pronounced benefit in terms of OS, ORR, and DOR from pembrolizumab over paclitaxel was seen in certain subgroups (performance status $0, \mathrm{CPS} \geq 10 \%$ and MSI-high). On the other hand, in the global JAVELIN Gastric 300 trial, the PD-L1 inhibitor avelumab failed to improve survival over physician's choice chemotherapy (mOS: 4.6 vs. 5.0 months, $p=0.81$, respectively) as third-line treatment in 371 mGC patients, regardless of PD-L1 status (TPS $\geq 1 \%$ ) [70]. Furthermore, the phase III JAVELIN Gastric 100 (NCT02625610), evaluating the role of avelumab as first-line maintenance treatment after an induction phase with XELOX/FOLFOX provided negative results in PD-L1 positive (TPS $\geq 1 \%$ ) mGC patients [71].

Combining immunotherapy and chemotherapy might be of benefit in improving immunogenicity, especially increasing TMB with platinum agents [72]. In the global phase III KEYNOTE-062 trial [73], 763 HER-2 negative and PD-L1 positive (CPS $\geq 1 \%$ ) untreated mGC patients were randomized to three arms with two comparisons: pembrolizumab alone vs. cisplatin and fluoropyrimidine (PF) (non-inferiority) and pembrolizumab plus PF vs. PF (superiority). Non-inferiority of pembrolizumab was demonstrated in terms of OS in CPS $\geq 1 \%$ (mOS 10.6 vs. 11.1 months, HR: 0.91, non-inferiority margin: 1.2), especially in CPS $\geq 10 \%$ (mOS 17.4 vs. 10.8 months, HR: 0.69), even if ORR and PFS were 
worse in the pembrolizumab arm in CPS $\geq 1 \%$ but better in CPS $\geq 10 \%$ patients. On the other hand, chemotherapy plus pembrolizumab was not formally superior to chemotherapy alone in terms of OS even if a favorable trend was seen both in CPS $\geq 1 \%$ (mOS 12.5 vs. 11.1 months, HR: $0.85, p=0.046$ ) and CPS $\geq 10 \%$ (mOS 12.3 vs. 10.8, HR: $0.85, p=0.158$ ) patients. In an exploratory analyses of this trial conducted among 50 MSI-high patients, median OS was not reached in both pembrolizumab arms compared with 8.5 months with chemotherapy alone, while ORR was almost doubled in both pembrolizumab arms compared to chemotherapy alone [74]. These data further support the FDA approval of pembrolizumab for PD-L1 $\geq 1 \%$ as well as agnostic indication for unresectable or metastatic mismatch repair deficient (dMMR) and/or MSI-high solid tumors, including GC, with no alternative options. On the other hand, the amount of negative results stresses the need to better define potential predictive biomarkers for immunotherapy in clinical trials with ICI (e.g., CPS maybe more reliable than TPS as assessor of PD-L1 status; PD-L1 threshold of $10 \%$ maybe more realistic than $1 \%$ ). For this purpose, it might be useful to refer to the four genomic subtypes of GC as defined by TGCA (EBV-positive [8\%], characterized by a higher prevalence of DNA hypermetilation, PD-L1/L2 amplification, PIK3CA and ARID1A mutations; MSI-positive [22\%], exhibiting high TMB, MLH1 promoter hypermetilation and PIK3CA mutations; genomically stable [GS, 20\%], harboring CDH1 and RHOA mutations and CLDN18-ARHGAP rearrangements; chromosomal instability positive [CIN, 50\%], harboring TP53 mutations as well RAS receptor tyrosine kinase pathway (i.e., VEGFA, EGFR, HER2-3, FGFR2) and cell cycle mediators (i.e., CDK6) amplifications) [55]. As told previously, MSI-high GC, maybe in relation with the dense concentration of CD8+ tumor-infiltrating lymphocytes (TILs) stimulated by immunogenic neoantigens in turn generated by a hypermutational load (TMB), are characterized by higher ORR compared with non-MSI-high GC [41,74,75]. The EBV subtype, characterized by increased PD-L1 expression in both tumor cells and TILs, seems to be even more responsive to ICI [75]. Gut microbiome has been shown to be associated with efficacy of anti-PD1 $\mathrm{mAb}$ in different types of cancer [76] and the DELIVER trial (JACCRO GC-08, UMIN000030850) is investigating the role of novel immune-related biomarkers (gut microbiome, genetic polymorphism, gene expression, and metabolome in plasma) in mGC patients treated with nivolumab.

Several trials are further investigating the role of PD-1/PD-L1 inhibitors in combination with chemotherapy as first- or second-line treatment for $\mathrm{mGC}$ as well as the potential role of combination with targeted agents (Table 2). Indeed, it is well recognized that tumor neovascularization promoted by tumor-induced angiogenic factors as VEGF can activate immunosuppressive cells as regulatory T cells (Treg) and tumor-associated macrophages (TAM), in turn involved in tumor progression, invasion, and angiogenesis downregulating anti-tumor TILs, especially CD8+ Cytotoxic T-Lymphocytes (CTLs) [77]. Antiangiogenic agents may restore the immune antitumor activity disrupting the VEGF/VEGFR axis inhibition in the tumor microenvironment [78]. Promising activity and efficacy results derived from phase I-II clinical trials combining ramucirumab with nivolumab (NivoRam) [79] or pembrolizumab (KEYNOTE-098) [80], or nivolumab with regorafenib (REGONIVO) [81], or lenvatinib plus pembrolizumab [82]. Exciting the combinations with chemotherapy evaluating the association of paclitaxel, ramucirumab and avelumab (RAP: NCT03966118) or pembrolizumab (SEQUEL: NCT04069273).

Ultimately, trastuzumab seems to upregulate the expression of PD-L1 and enhance gene expression signature of immune infiltration [83], providing a rationale for combination with ICI. In the phase II 16-937 trial [84], 37 HER2-positive mGC treated with XELOX and trastuzumab in combination with pembrolizumab as first-line therapy, reaching an ORR and a 6-month PFS of $91 \%$ and $70 \%$, respectively. The confirmatory phase III KEYNOTE-811 (NCT03615326) trial is ongoing (Table 2). 
Table 2. List of ongoing phase III or II/III trials with immune checkpoint inhibitors in metastatic gastric cancer.

\begin{tabular}{|c|c|c|c|c|c|c|c|c|}
\hline $\begin{array}{l}\text { Study Name } \\
\text { [reference] }\end{array}$ & Country & $\mathrm{Ph}$ & Line & $\mathbf{N}$ & Drugs (Target) & $\begin{array}{l}\text { Selected } \\
\text { Population }\end{array}$ & $\begin{array}{c}\text { Study Intervention } \\
\text { Experimental Arm/Control Arm }\end{array}$ & PE \\
\hline $\begin{array}{l}\text { SHR-1210-III-316 } \\
\text { NCT04342910 }\end{array}$ & China & III & $2^{\circ}$ & 550 & $\begin{array}{l}\text { Camrelizumab (PD-1) } \\
\text { Apatinib (VEGFR2) }\end{array}$ & All comers & $\begin{array}{l}\text { Camrelizumab }+ \text { apatinib } \\
\text { paclitaxel or irinotecan }\end{array}$ & OS \\
\hline $\begin{array}{l}\text { ATTRACTION-04 } \\
\text { (NCT02746796) }\end{array}$ & Asia & II-III & $1^{\circ}$ & 680 & Nivolumab (PD-1) & HER2 neg & $\begin{array}{l}\text { CAPOX (SOX) + nivolumab } \\
\text { CAPOX (SOX) + placebo }\end{array}$ & OS, PFS \\
\hline $\begin{array}{l}\text { MAHOGANY } \\
\text { (NCT04082364) }\end{array}$ & US & II-III & $1^{\circ}$ & 850 & $\begin{array}{l}\text { MGA012 (PD-1) } \\
\text { MGD013 (PD-1/LAG-3) } \\
\text { Margetuximab (HER2) }\end{array}$ & $\begin{array}{c}\text { Cohort A: } \\
\text { HER2/PD-L1 pos } \\
\text { Cohort B: } \\
\text { HER2 pos }\end{array}$ & $\begin{array}{c}\text { Margetuximab + MGA012 } \\
\text { XELOX (mFOLFOX6) + margetuximab + MGA012 } \\
\text { XELOX (mFOLFOX6) + margetuximab + MGD013 } \\
\text { XELOX (mFOLFOX6) + margetuximab } \\
\text { XELOX (mFOLFOX6) + trastuzumab }\end{array}$ & $\begin{array}{l}\text { Cohort A: ORR } \\
\text { Cohort B: OS }\end{array}$ \\
\hline $\begin{array}{l}\text { KEYNOTE-063 } \\
\text { (NCT03019588) }\end{array}$ & Asia & III & $2^{\circ}$ & 360 & Pembrolizumab (PD-1) & PD-L1 pos & $\begin{array}{l}\text { Pembrolizumab } \\
\text { PTX }\end{array}$ & OS, PFS \\
\hline $\begin{array}{l}\text { GEMSTONE-303 } \\
\text { (NCT03802591) }\end{array}$ & China & III & $1^{\circ}$ & 480 & CS1001 (PD-L1) & HER2 neg & $\begin{array}{l}\text { XELOX + CS1001 } \\
\text { XELOX + placebo }\end{array}$ & OS, PFS \\
\hline $\begin{array}{l}\text { SHR-1210-III-311 } \\
\text { (NCT03813784) }\end{array}$ & China & III & $1^{\circ}$ & 568 & $\begin{array}{l}\text { SHR-1210 (PD-1) } \\
\text { Apatinib (VEGFR2) }\end{array}$ & HER2 neg & $\begin{array}{c}\text { apatinib + SHR-1210 after XELOX + SHR-1210 } \\
\text { XELOX }\end{array}$ & OS \\
\hline $\begin{array}{l}\text { CIBI308E301 } \\
\text { (NCT03745170) }\end{array}$ & China & III & $1^{\circ}$ & 650 & Sintilimab (PD-1) & HER2 neg & $\begin{array}{l}\text { XELOX + sintilimab } \\
\text { XELOX + placebo }\end{array}$ & OS \\
\hline $\begin{array}{l}\text { KEYNOTE-811 } \\
\text { (NCT03615326) }\end{array}$ & Global & III & $1^{\circ}$ & 732 & $\begin{array}{l}\text { Pembrolizumab (PD-1) } \\
\text { Trastuzumab (HER2 }\end{array}$ & HER2 pos & $\begin{array}{c}\text { FP/XELOX/SOX + trastuzumab + } \\
\text { pembrolizumab } \\
\text { FP/XELOX/SOX + trastuzumab + placebo }\end{array}$ & OS, PFS \\
\hline $\begin{array}{l}\text { KEYNOTE-859 } \\
(\text { NCT03675737) }\end{array}$ & Global & III & $1^{\circ}$ & 780 & Pembrolizumab (PD-1) & HER2 neg & $\begin{array}{l}\text { FP/XELOX + pembrolizumab } \\
\text { FP/XELOX + placebo }\end{array}$ & OS, PFS \\
\hline $\begin{array}{r}\text { BGB-A317-305 } \\
\text { (NCT03777657) }\end{array}$ & Global & III & $1^{\circ}$ & 720 & Tislelizumab (PD-1) & HER2 neg & $\begin{array}{l}\text { XELOX (FP) + tislelizumab } \\
\text { XELOX (FP) + placebo }\end{array}$ & OS, PFS \\
\hline NCT04435652 & NA & II-III & $2^{\circ}$ & 492 & QL1604 (PD-1) & HER2 neg & $\begin{array}{c}\text { QL1604 + nab-paclitaxel followed by QL1604 } \\
\text { maintenance. } \\
\text { paclitaxel alone }\end{array}$ & ORR, safety, OS \\
\hline
\end{tabular}

Ph: phase; PE: primary endpoint; XELOX: capecitabine + oxaliplatin; DCR: disease control rate; DOR: duration of response; FOLFIRI: 5-FU + leucovorin + irinotecan; FP: 5-FU + cisplatin; mFOLFOX6: modified FOLFOX6 (5-FU + leucovorin + oxaliplatin); ORR: objective response rate; OS: overall survival; PFS: progression-free survival; PTX: paclitaxel; SOX: S-1 + oxaliplatin;

SP: S-1 + cisplatin; XP: capecitabine + cisplatin. 


\section{Surgery and Locoregional Treatments}

If surgery represents the cornerstone of treatment in the early or locally advanced GC, eventually associated with neoadjuvant [85] or adjuvant [86] systemic treatment according to local guidelines and clinical practice, its role in the metastatic disease is still far from clear.

Theoretically, gastrectomy might reduce a large and immunosuppressive tumor burden, removing the source of new metastases and improving symptoms related to the primary tumor such as bleeding, perforation, and obstruction. On the contrary, gastrectomy could lead to disease progression inducing immunosuppression, delaying systemic treatment delivery as a consequence of postoperative complications, or making systemic treatment less tolerable.

The role of the surgical resection of the primary tumor has been investigated in the Asian phase III REGATTA trial [11], in which primary tumor resection followed by systemic treatment provided no survival benefit compared to systemic treatment alone (mOS 14.3 vs. 16.6 months, respectively, $\mathrm{HR}=1.09, p=0.70$ ) in mGC patients with a single non-curable factor, resulting even detrimental. It is important to underline that in this trial, resection of metastatic lesions was not allowed and this could at least in part have influenced the negative results.

Indeed, a growing amount of evidences showed a possible role of both gastrectomy and metastases treatment, especially in case of liver involvement, occurring in about $40 \%$ of the cases of synchronous disease, $70 \%$ of which confined to the liver with no diffusion to other organs [87]. In a recent systematic review and pooled analysis of 39 both Eastern (30) and Western (9) studies published over 25 years and including $991 \mathrm{mGC}$ patients who underwent resection for liver metastases, the median 1-year, 3-year, and 5-year survival in Eastern/Western populations was $73 / 59 \%, 34 / 24.5 \%$, and $27 / 16.5 \%$, respectively [14]. Liver metastases resection was associated with a significantly improved overall survival $(\mathrm{HR}=0.5 ; p<0.001)$ and a median 30-day morbidity and mortality of $24 \%$ and $0 \%$, respectively [14]. Even if deriving from small and retrospective studies, heterogeneous for selection criteria and for the eventually performed pre- or postoperative systemic treatment, these data support the possibility for carefully selected "oligometastatic" GC patients (i.e., patients with solitary and unilobar liver-only metastasis, R0 resectable, with complete removal of primary gastric tumor and lymph nodes for synchronous metastases) to achieve long-term benefit from a multimodality treatment strategy. In the arm B of the phase II AIO/FLOT3 trial [20], a three-arm, prospective, non-randomized study, 60 patients with limited mGC (i.e., retroperitoneal lymph node metastases with no diffuse nor symptomatic nor clinically detectable peritoneal carcinomatosis, with or without one of the following: $<5$ liver lesions or Krukemberg tumors or adrenal gland metastases) received 4 cycles of FLOT regimen (5-fluorouracil, oxaliplatin, and docetaxel) followed by radical macroscopic surgery of both primary tumor and metastases, whenever feasible, and then 4 subsequent postoperative FLOT cycles (arm B). Arm A and arm $C$ of the study consisted of patients with locally advanced and widely metastatic disease, respectively, and received perioperative ( $\operatorname{arm~A)}$ and palliative ( $\operatorname{arm} C)$ FLOT. In the arm B, $36(60 \%)$ patients underwent surgery, with improved survival compared to those who did not (mOS 31.3 vs. 15.9 months, respectively) or those with extensive metastatic disease (mOS 10.7 months). The ongoing phase III RENAISSANCE/AIO-FLOT5 trial (NCT02578368) will confirm the role of a multimodal treatment over systemic treatment alone in oligometastatic GC patients (Table 3).

Besides resection, other locoregional treatments such as radiofrequency ablation (RFA), microwave ablation (MWA) [16], hepatic artery infusion chemotherapy (HAIC) [17], transarterial chemoembolization (TACE) [18], and stereotactic body radiotherapy (SBRT) [19] have been investigated in mGC. Overall, these treatments were less invasive and associated with less minor and major complications, resulting at least non-inferior if compared to resection in highly-selected mGC patients with small (e.g., $<3-5 \mathrm{~cm}$ in size for RFA and MWA) liver-limited lesions [16]. Of course, proper designed studies are warranted to better define the role of these treatments as potentially alternative or complementary to surgery and systemic treatment in selected mGC patients. 
Table 3. List of ongoing or completed phase III or II-III trials evaluating surgery and locoregional treatments in metastatic gastric cancer.

\begin{tabular}{|c|c|c|c|c|c|c|c|}
\hline Study name & Country & $\mathrm{Ph}$ & Line & $\mathbf{N}$ & Selected Population & $\begin{array}{c}\text { Study Intervention } \\
\text { Experimental Arm/Control Arm }\end{array}$ & PE \\
\hline $\begin{array}{c}\text { SURGIGAST } \\
\text { (NCT03042169) }\end{array}$ & France & III & $1^{\circ}$ & 424 & $\begin{array}{c}\text { GC with a single metastatic site regardless the } \\
\text { number of lesions involving the site, in addition } \\
\text { to the resectable PTS }\end{array}$ & $\begin{array}{l}\text { CT followed by PTS resection } \\
\text { followed by CT } \\
\text { CT }\end{array}$ & OS \\
\hline REGATTA [11] & Asian & III & $1^{\circ}$ & 175 & $\begin{array}{l}\text { GC with resectable PTS and a single non-curable } \\
\text { factor ( } 2-4 \text { liver mets of at least } 1 \mathrm{~cm} \text {, peritoneal } \\
\text { mets in the diaphragm or peritoneum caudal to } \\
\text { the transverse colon without massive ascites or } \\
\text { intestinal obstruction; para-aortic lymph node } \\
\text { metastasis above the coeliac axis or below the } \\
\text { inferior mesenteric artery) }\end{array}$ & $\begin{array}{l}\text { PTS resection followed by } \mathrm{CT} \\
\qquad \mathrm{CT}\end{array}$ & OS (NEG) \\
\hline $\begin{array}{l}\text { EA2183 } \\
\text { ECOG-ACRIN Cancer } \\
\text { Research Group } \\
\text { (NCT04248452) }\end{array}$ & US & III & any & 314 & $\begin{array}{c}\text { GC and EGC with at most } 3 \text { metastatic lesions, } \\
\text { in addition to the resectable PTS } \\
\text { HER2 negative }\end{array}$ & $\begin{array}{c}\text { FOLFOX alone } \\
\text { XELOX alone } \\
\text { FOLFOX followed by RT } \\
\text { followed by FOLFOX } \\
\text { XELOX followed by RT followed } \\
\text { by XELOX }\end{array}$ & OS \\
\hline $\begin{array}{l}\text { FLOT5- } \\
\text { RENAISSANCE } \\
\text { (NCT02578368) }\end{array}$ & Germany & III & $1^{\circ}$ & 271 & $\begin{array}{l}\text { GC with retroperitoneal lymph node mets } \\
\text { and/or at maximum one organ involved in } \\
\text { addition to the resectable PTS }\end{array}$ & $\begin{array}{c}\text { FLOT } \pm \text { Trastuzumab followed by } \\
\text { PTS resection }+ \text { metastasectomy } \\
\text { followed by FLOT } \pm \text { Trastuzumab } \\
\text { FLOT } \pm \text { Trastuzumab }\end{array}$ & OS \\
\hline $\begin{array}{l}\text { GASTRIPEC } \\
(\text { NCT02158988) }\end{array}$ & Germany & III & $1^{\circ}$ & 105 & $\begin{array}{l}\text { GC and EGC with no other than peritoneal } \\
\text { carcinomatosis regardless previous PTS resection }\end{array}$ & $\begin{array}{c}\text { Preop EOX (CXT) followed by } \\
\text { surgery }+ \text { HIPEC with cisplatin } \\
\text { and mytomicin C followed by } \\
\text { postop EOX (CXT) } \\
\text { Preop EOX (CXT) followed by } \\
\text { surgery followed by postop EOX } \\
\text { (CXT) }\end{array}$ & OS \\
\hline
\end{tabular}


Table 3. Cont.

\begin{tabular}{|c|c|c|c|c|c|c|c|}
\hline Study name & Country & $\mathbf{P h}$ & Line & $\mathbf{N}$ & Selected Population & $\begin{array}{c}\text { Study Intervention } \\
\text { Experimental Arm/Control Arm }\end{array}$ & PE \\
\hline $\begin{array}{l}\text { PERISCOPE II } \\
\text { (NCT03348150) }\end{array}$ & Netherlanc & dsII & any & 106 & $\begin{array}{c}\text { GC with no other than limited peritoneal } \\
\text { carcinomatosis }(\mathrm{PCI}<7) \text { and/or positive } \mathrm{PC} \text {, in } \\
\text { addition to PTS }\end{array}$ & $\begin{array}{c}\text { Gastrectomy + cytoreductive } \\
\text { surgery + HIPEC after SOC CT } \\
\text { SOC CT }\end{array}$ & OS \\
\hline $\begin{array}{l}\text { NEO-REGATTA } \\
\text { (NCT03001726) }\end{array}$ & China & III & any & 188 & $\begin{array}{l}\text { GC with a single non-curable factor defined as: } \\
2-4 \text { hepatic mets } \leq 5 \mathrm{~cm} \text { or positive PC or single } \\
\text { peritoneal met with no massive ascites or PAN } \\
\text { mets or ovary implant mets) }\end{array}$ & $\begin{array}{l}\text { SLOT followed by PTS resection }+ \\
\text { metastasectomy followed by } \\
\text { SLOT } \\
\text { SLOT alone }\end{array}$ & OS \\
\hline $\begin{array}{c}\text { LP0190415 } \\
\text { (NCT04222114) }\end{array}$ & NA & II-III & $>3^{\circ}$ & 282 & Peritoneal mets & $\begin{array}{l}\text { Intra-peritoneal catumaxomab } \\
\text { (EpCAM inhibitor) } \\
\text { Investigator choice CT }\end{array}$ & OS \\
\hline
\end{tabular}

CT: chemotherapy; RT: radiation therapy; GC: gastric cancer; EGC: esophagogastric cancer; PTS: primary tumor site; EOX: epirubicin + oxaliplatin + capecitabine; CXT: cisplatin + capecitabine + trastuzumab; met: metastasis; PC: peritoneal citology; PCI: peritoneal cancer index; NEG: negative; PAN: para-aortic lymph node; SLOT: S1 + oxaliplatin + docetaxel; SOC: standard of care; EpCAM: epithelial cell adhesion molecule. 
Peritoneal metastases occur in above $40 \%$ of synchronous disease and up to $46 \%$ of metachronous cases, in above $70 \%$ of the patients with no other organs involvement [88]. Malignant ascites, bowel obstruction, and nutritional impairment caused by peritoneal carcinomatosis lead to both poor survival and QoL in mGC patients [89]. To improve both survival and symptoms control for GC patients with peritoneal metastases, cytoreductive surgery (CRS) followed by hypertermic intraperitoneal chemotherapy (HIPEC) have been investigated during the last decades [88]. CRS is a complex surgical procedure including peritonectomy and resection of involved viscera with the aim of removing macroscopic disease [90]. The biological rationale for intraperitoneal delivery is based on preclinical evidences of a pharmacokinetic advantage explained by the existence of a peritoneal-plasma barrier, allowing a high concentration gradient of chemotherapeutic drugs between the peritoneal cavity and the systemic circulation [91]. An additional advantage to intraperitoneal chemotherapy administration is that blood drainage from the peritoneal cavity is through the portal system, providing a detoxifying "first-pass" effect, reducing systemic toxicity [92]. Furthermore, experimental and clinical evidences highlight how malignant cells are selectively destroyed by hyperthermia in the range of $41-43^{\circ} \mathrm{C}$ [93], especially when selected drugs (i.e., taxanes, platinum compounds, mitomycin $\mathrm{C}$, and anthracyclines) are used [94]. In a recent meta-analysis of 11 randomized and 21 non-randomized comparative studies published over 30 years and including 2520 mGC patients, CRS plus HIPEC is associated with longer mOS compared to the control group (11.1 vs. 7.0 months) in selected patients with positive peritoneal citology only, or limited nodal involvement, or with extensive carcinomatosis in which a radical cytoreductive surgery can be achieved. This benefit is associated to significantly higher risk of postoperative complications (RR: 2.15), in particular, respiratory and renal failure [15]. Because of the technical complexity, the high risk of postoperative complications and since the likelihood of a complete macroscopic cytoreduction is related to a surgeon's experience, CRS and HIPEC should only be performed in specialized high-volume centers [93]. Recently, the most significant development in intraperitoneal-directed therapy is pressurized intraperitoneal aerosol chemotherapy (PIPAC), a minimally invasive procedure, generally safe and well tolerated, capable of achieving a more uniform distribution and deeper peritoneal penetration in gaseous state when compared to liquid chemotherapy [94]. Data on efficacy and safety of PIPAC in GC patients with peritoneal metastases remains limited, with only 4 studies (2 retrospective studies and 2 phase II trials), comprising a total of 274 PIPAC procedures administered in 119 GC patients [94-97]. In these studies, mOS rates, major complication rates, and mortality rates ranged between $4.0-19.5$ months, $0-29 \%$ and $0-8.3 \%$, respectively [94-97]. The multicenter, international online documentation of indications and results of PIPAC (PIPACRegis-NCT03210298), is an international prospective patient registry intended to collect clinical data from 1000 cancer patients undergoing PIPEC.

Results of ongoing randomized phase II-III clinical trials evaluating the efficacy of multimodal approaches in mGC patients are highly awaited (Table 3).

\section{Sarcopenia, Cachexia, Malnutrition, and Supportive Care}

GC is among the leading oncologic causes of sarcopenia, a complex syndrome characterized by progressive and generalized loss of skeletal muscle mass and strength, fatigue, and metabolic disorders, ultimately resulting in a condition of body weight loss and then cachexia in $85 \%$ of the cases $[98,99]$. In turn, cachexia, defined as a body weight loss more than $5 \%$ within 12 months or less, contributes substantially to morbidity and mortality in cancer patients, accounting for more than $20 \%$ of cancer deaths $[98,100]$. The cachectic state is a life-threatening syndrome encompassing skeletal muscle and adipose tissue loss, and it is frequently associated with muscle atrophy and a deregulated metabolic state characterized by insulin resistance, reduced anabolic activity, elevated cortisol levels, increased basal energy expenditure, and resistance to conventional nutritional support [101]. It results from an extensive interaction between proinflammatory cytokines (i.e., IL-1, IL-6, TNF-a, and others) and neuroendocrine factors generated by both tumor and host cells [100]. Additionally, cachexia-associated cytokines are able to cross the blood-brain barrier and modify the activity of hunger regulatory systems. 
As a result, from $15 \%$ to $40 \%$ of cancer patients with cachexia often develop anorexia [101], establishing a vicious cycle of malnutrition, sarcopenia, and cachexia.

Sarcopenia is a well-known independent predictor of short- and long-term postsurgical outcome in GC [21,102], associated to higher postsurgical complication rate (i.e., infection rate), longer hospitalization, more frequent need of mechanical ventilation, and a greater number of hospital readmissions, ultimately leading to poor DFS and OS. Likewise, sarcopenia is associated with toxicity in GC patients undergoing perioperative systemic treatment for early stage of disease $[22,23,103]$ or multiple lines of therapy in the metastatic setting [35], leading to early discontinuation of treatment, reduced efficacy of antineoplastic agents, and poor prognosis.

With these thought in mind, it is important to carry out an overall assessment of the nutritional status and symptoms burden of the mGC patient in each moment of his natural history, using well-recognized clinical (i.e., Mini Nutritional Assessment (MNA) [104] and PERSONS score [105,106] in addition to body mass index (BMI) and body surface area (BSA) [98]), biochemical (i.e., C-reactive protein and albumin ratio [107]) and instrumental (i.e., radiological evaluation of skeletal muscle mass, skeletal muscle index, and skeletal muscle radiodensity $[108,109])$ parameters, to promptly identify, grading, monitoring, and treating risk and causes of malnutrition, sarcopenia, and cachexia. Indeed, the early integration of nutritional screening, personalized nutritional support, and prehabilitation programs with physical exercise, has been shown to increase muscle mass and prevent or limit sarcopenia, with better short- and long-term post-gastrectomy outcomes [110]. In mGC patients frequently affected by impaired gastrointestinal function and inadequate food intake as a consequence of dysphagia or obstruction, nutritional support provided by oral, enteral, and/or parenteral nutrition may improve patients' QoL and adherence to systemic therapies [111]. Many molecules, including anabolic agents and anti-inflammatory drugs, have been developed to limit sarcopenia and cachexia. Megestrol acetate and medroxyprogesterone acetate, alone [112] or combined with other compounds such as formeterol acetate and mirtazapine [113] demonstrated to stimulate appetite and weight gain, downregulating proinflammatory citokines. Similarly, corticosteroids could improve appetite, asthenia, energy, and wellness [114]. If the ongoing phase III EPIC-1511 trial (NCT2853474) will better define the importance of the early integration of supportive care in addition to SOC treatment with respect to SOC alone and palliative care as needed in upper gastrointestinal cancer patients, there is no doubt that new drugs to counter body mass loss and increase the efficacy of nutritional support in GC patients are urgently required.

\section{Concluding Remarks}

In recent years, multiple targeted agents and immunotherapy drugs have been investigated in mGC, providing mostly negative results in unselected or poorly selected patients, but with evidence of promising survival and clinical benefit for certain subgroups. On the other hand, "oligometastatic" GC would increasingly seem to be a clinical entity with distinct prognosis and therapeutic implications, able to benefit from a multimodality approach including systemic, surgical, and locoregional treatments. Therefore, it is imperative to find and define specific and proper clinical biomarkers for targeted and immunotherapy agents and selection criteria for surgical and locoregional therapies. At the same time, early evaluations of nutritional status and timely nutritional support are key aspects capable of improving prognosis in all the phases and settings of GC disease.

Author Contributions: Conceptualization, A.P.; Supervision, G.P. and C.F.; Writing-original draft, A.P.; Writing-review \& editing, G.P. and C.F. All authors have read and agreed to the published version of the manuscript.

Funding: This research did not receive any specific grant from funding agencies in the public, commercial, or not-for-profit sectors.

Conflicts of Interest: The authors declare no conflict of interest. 


\section{References}

1. Ferlay, J.; Colombet, M.; Soerjomataram, I.; Mathers, C.; Parkin, D.M.; Pineros, M.; Znoar, A.; Bray, F. Estimating the global cancer incidence and mortality in 2018: GLOBOCAN sources and methods. Int. J. Cancer 2019, 144, 1941-1953. [CrossRef] [PubMed]

2. Ajani, J.A.; Lee, J.; Sano, T.; Janjigian, Y.Y.; Fan, D.; Song, S. Gastric adenocarcinoma. Nat. Rev. Dis. Primers 2017, 1, 17036. [CrossRef] [PubMed]

3. Wagner, A.D.; Syn, N.L.; Moehler, M.; Grothe, W.; Yong, W.P.; Tai, B.C.; Ho, J.; Unverzagt, S. Chemotherapy for advanced gastric cancer. Cochrane Database Syst. Rev. 2017, 29, CD004064. [CrossRef]

4. Bang, Y.J.; Van Cutsem, E.; Feyereislova, A.; Chung, H.C.; Shen, L.; Sawaki, A.; Lordick, F.; Ohtsu, A.; Omuro, Y.; Satoh, T.; et al. Trastuzumab in combination with chemotherapy versus chemotherapy alone for treatment of HER2-positive advanced gastric or gastro-oesophageal junction cancer (ToGA): A phase 3, open-label, randomised controlled trial. Lancet 2010, 376, 687-697. [CrossRef]

5. Fuchs, C.S.; Tomasek, J.; Yong, C.J.; Dumitru, F.; Passalacqua, R.; Goswami, C.; Safran, H.; Dos Santos, L.V.; Aprile, G.; Ferry, D.R.; et al. Ramucirumab monotherapy for previously treated advanced gastric or gastro-oesophageal junction adenocarcinoma (REGARD): An international, randomised, multicentre, placebo-controlled, phase 3 trial. Lancet 2014, 383, 31-39. [CrossRef]

6. Wilke, H.; Muro, K.; Van Cutsem, E.; Oh, S.C.; Bodoky, G.; Shimada, Y.; Hironaka, S.; Sugimoto, N.; Lipatov, O.; Kim, T.Y.; et al. Ramucirumab plus paclitaxel versus placebo plus paclitaxel in patients with previously treated advanced gastric or gastro-oesophageal junction adenocarcinoma (RAINBOW): A double-blind, randomised phase 3 trial. Lancet Oncol. 2014, 15, 1224-1235. [CrossRef]

7. Li, J.; Qin, S.; Xu, J.; Xiong, J.; Wu, C.; Bai, Y.; Liu, W.; Tong, J.; Liu, Y.; Xu, R.; et al. Randomized, double-blind, placebo controlled phase III trial of apatinib in patients with chemotherapy-refractory advanced or metastatic adenocarcinoma of the stomach or gastroesophageal junction. J. Clin. Oncol. 2016, 34, 1448-1454. [CrossRef]

8. Shitara, K.; Doi, T.; Dvorkin, M.; Mansoor, W.; Arkenau, H.T.; Prokharau, A.; Alsina, M.; Ghidini, M.; Faustino, C.; Gorbunova, V.; et al. Trifluridine/tipiracil versus placebo in patients with heavily pretreated metastatic gastric cancer (TAGS): A randomised, double-blind, placebo-controlled, phase 3 trial. Lancet Oncol. 2018, 19, 1437-1448. [CrossRef]

9. Kang, Y.K.; Boku, N.; Satoh, T.; Ryu, M.H.; Chao, Y.; Kato, K.; Chung, H.C.; Chen, J.S.; Muro, K.; Kang, W.K.; et al. Nivolumab in patients with advanced gastric or gastro-oesophageal junction cancer refractory to, or intolerant of, at least two previous chemotherapy regimens (ONO-4538-12, ATTRACTION-2): A randomised, double-blind, placebo-controlled, phase 3 trial. Lancet 2017, 390, 2461-2471. [CrossRef]

10. Chen, C.; Zhang, F.; Zhou, N.; Gu, Y.M.; Zhang, Y.T.; He, Y.D.; Wang, L.; Yang, L.X.; Zhao, Y.; Li, Y.M. Efficacy and safety of immune checkpoint inhibitors in advanced gastric or gastroesophageal junction cancer: A systematic review and meta-analysis. Oncoimmunology 2019, 8, e1581547. [CrossRef]

11. Fujitani, K.; Yang, H.K.; Mizusawa, J.; Kim, Y.W.; Terashima, M.; Han, S.U.; Iwasaki, Y.; Hyung, W.J.; Takagane, A.; Park, D.J.; et al. Gastrectomy plus chemotherapy versus chemotherapy alone for advanced gastric cancer with a single non-curable factor (REGATTA): A phase 3, randomised controlled trial. Lancet Oncol. 2016, 17, 309-318. [CrossRef]

12. Warschkow, R.; Baechtold, M.; Leung, K.; Schmied, B.M.; Nussbaum, D.P.; Gloor, B.; Blazer, D.G., III; Worni, M. Selective survival advantage associated with primary tumor resection for metastatic gastric cancer in a Western population. Gastric Cancer 2018, 21, 324-337. [CrossRef] [PubMed]

13. Gadde, R.; Tamariz, L.; Hanna, M.; Avisar, E.; Livingstone, A.; Franceschi, D.; Yakoub, D. Metastatic gastric cancer (MGC) patients: Can we improve survival by metastasectomy? A systematic review and meta-analysis. J. Surg. Oncol. 2015, 112, 38e45. [CrossRef]

14. Markar, S.R.; Mikhail, S.; Malietzis, G.; Athanasiou, T.; Mariette, C.; Sasako, M.; Hanna, G.B. Influence of Surgical Resection of Hepatic Metastases from Gastric Adenocarcinoma on Long-term Survival: Systematic Review and Pooled Analysis. Ann. Surg. 2016, 263, 1092-1101. [CrossRef]

15. Desiderio, J.; Chao, J.; Melstrom, L.; Warner, S.; Tozzi, F.; Fong, Y.; Parisi, A.; Woo, Y. The 30-year experience-A meta-analysis of randomised and high-quality non-randomised studies of hyperthermic intraperitoneal chemotherapy in the treatment of gastric cancer. Eur. J. Cancer 2017, 79, 1-14. [CrossRef] [PubMed] 
16. Tang, K.; Liu, Y.; Dong, L.; Zhang, B.; Wang, L.; Chen, J.; Chen, G.; Tang, Z. Influence of thermal ablation of hepatic metastases from gastric adenocarcinoma on long-term survival: Systematic review and pooled analysis. Medicine 2018, 97, e13525. [CrossRef]

17. Fukami, Y.; Kaneoka, Y.; Maeda, A.; Takayama, Y.; Takahashi, T.; Uji, M.; Kumada, T. Adjuvant hepatic artery infusion chemotherapy after hemihepatectomy for gastric cancer liver metastases. Int. J. Surg. 2017, 46, 79-84. [CrossRef]

18. Liu, S.F.; Lu, C.R.; Cheng, H.D.; Xi, H.Q.; Cui, J.X.; Li, J.Y.; Shen, W.S.; Chen, L. Comparison of Therapeutic Efficacy between Gastrectomy with Transarterial Chemoembolization Plus Systemic Chemotherapy and Systemic Chemotherapy Alone in Gastric Cancer with Synchronous Liver Metastasis. Chin. Med. J. (Engl.) 2015, 128, 2194-2201. [CrossRef]

19. Lewis, G.D.; Chiang, S.B.; Butler, E.B.; Teh, B.S. The utility of positron emission tomography/computed tomography in target delineation for stereotactic body radiotherapy for liver metastasis from primary gastric cancer: An illustrative case report and literature review. J. Gastrointest. Oncol. 2017, 8, E39-E42. [CrossRef]

20. Al-Batran, S.E.; Homann, N.; Pauligk, C.; Illerhaus, G.; Martens, U.M.; Stoehlmacher, J.; Schmalenberg, H.; Luley, K.B.; Prasnikar, N.; Egger, M.; et al. Effect of neoadjuvant chemotherapy followed by surgical resection on survival in patients with limited metastatic gastric or gastroesophageal junction cancer: The AIO-FLOT3 trial. JAMA Oncol. 2017, 3, 1237e44. [CrossRef]

21. Wang, S.-L.; Zhuang, C.-L.; Huang, D.-D.; Pang, W.-Y.; Lou, N.; Chen, F.-F.; Zhou, C.J.; Shen, X.; Yu, Z. Sarcopenia adversely impacts postoperative clinical outcomes following gastrectomy in patients with gastric cancer: A prospective study. Ann. Surg. Oncol. 2016, 23, 556-564. [CrossRef] [PubMed]

22. Park, H.S.; Kim, H.S.; Beom, S.H.; Rha, S.Y.; Chung, H.C.; Kim, J.H.; Chun, Y.J.; Lee, S.W.; Choe, E.A.; Heo, S.J.; et al. Marked Loss of Muscle, Visceral Fat, or Subcutaneous Fat After Gastrectomy Predicts Poor Survival in Advanced Gastric Cancer: Single-Center Study from the CLASSIC Trial. Ann. Surg. Oncol. 2018, 25, 3222-3230. [CrossRef] [PubMed]

23. Tan, B.H.L.; Brammer, K.; Randhawa, N.; Welch, N.T.; Parsons, S.L.; James, E.J.; Catton, J.A. Sarcopenia is associated with toxicity in patients undergoing neo-adjuvant chemotherapy for oesophago-gastric cancer. Eur. J. Surg. Oncol. 2015, 41, 333-338. [CrossRef]

24. Cunningham, D.; Starling, N.; Rao, S.; Iveson, T.; Nicolson, M.; Coxon, F.; Middleton, G.; Daniel, F.; Oates, J.; Norman, A.R.; et al. Capecitabine and oxaliplatin for advanced esophagogastric cancer. N. Engl. J. Med. 2008, 358, 36-46. [CrossRef]

25. Guimbaud, R.; Louvet, C.; Ries, P.; Ychou, M.; Maillard, E.; Andrè, T.; Gornet, J.M.; Aparicio, T.; Nguyen, S.; Azzedine, A.; et al. Prospective, randomized, multicenter, phase III study of fluorouracil, leucovorin, and irinotecan versus epirubicin, cisplatin, and capecitabine in advanced gastric adenocarcinoma: A French intergroup (Fédération Francophone de Cancérologie Digestive, Fédération Nationale des Centres de Lutte Contre le Cancer, and Groupe Coopérateur Multidisciplinaire en Oncologie) study. J. Clin. Oncol. 2014, 32, 3520-3526. [CrossRef]

26. Elimova, E.; Janjigian, Y.Y.; Mulcahy, M.; Catenacci, D.V.; Blum, M.A.; Almhanna, K.; Hecht, J.R.; Ajani, J.A. It Is Time to Stop Using Epirubicin to Treat Any Patient with Gastroesophageal Adenocarcinoma. J. Clin. Oncol. 2017, 35, 475-477. [CrossRef] [PubMed]

27. Mohammad, N.H.; ter Veer, E.; Ngai, L.; Mali, R.; van Oijen, M.G.; van Laarhoven, H.W. Optimal first-line chemotherapeutic treatment in patients with locally advanced or metastatic esophagogastric carcinoma: Triplet versus doublet chemotherapy: A systematic literature review and meta-analysis. Cancer Metastasis Rev. 2015, 34, 429-441. [CrossRef]

28. Van Cutsem, E.; Moiseyenko, V.M.; Tjulandin, S.; Majlis, A.; Constenla, M.; Boni, C.; Rodrigues, A.; Fodor, M.; Chao, Y.; Voznyi, E.; et al. Phase III study of docetaxel and cisplatin plus fluorouracil compared with cisplatin and fluorouracil as first-line therapy for advanced gastric cancer: A report of the V325 Study Group. J. Clin. Oncol. 2006, 24, 4991-4997. [CrossRef]

29. Shah, M.A.; Janjigian, Y.Y.; Stoller, R.; Shibata, S.; Kemeny, M.; Krishnamurthi, S.; Su, Y.B.; Ocean, A.; Capanu, M.; Mehrotra, B.; et al. Randomized multicenter phase II study of modified docetaxel, cisplatin, and fluorouracil (DCF) versus DCF plus growth factor support in patients with metastatic gastric adenocarcinoma: A study of the US gastric cancer consortium. J. Clin. Oncol. 2015, 33, 3874-3879. [CrossRef] 
30. Van Cutsem, E.; Boni, C.; Tabernero, J.; Massuti, B.; Middleton, G.; Dane, F.; Reichardt, P.; Pimentel, F.L.; Cohn, A.; Follana, P.; et al. Docetaxel plus oxaliplatin with or without fluorouracil or capecitabine in metastatic or locally recurrent gastric cancer: A randomized phase II study. Ann. Oncol. 2015, 26, 149-156. [CrossRef]

31. Cortellini, A.; Cannita, K.; Parisi, A.; Venditti, O.; Lanfiuti Baldi, P.; De Berardis, B.; Vicentini, R.; Vicentini, V.; Verna, L.; Porzio, G.; et al. Timed-flat infusion of 5-fluorouracil with docetaxel and oxaliplatin as first-line treatment of gastroesophageal adenocarcinoma: A single institution experience with the FD/FOx regimen. Oncol. Rep. 2018, 40, 803-812. [CrossRef] [PubMed]

32. Cremolini, C.; Loupakis, F.; Masi, G.; Lonardi, S.; Granetto, C.; Mancini, M.L.; Chiara, S.; Moretto, R.; Rossini, D.; Vitello, S.; et al. FOLFOXIRI or FOLFOXIRI plus bevacizumab as first-line treatment of metastatic colorectal cancer: A propensity score-adjusted analysis from two randomized clinical trials. Ann. Oncol. 2016, 27, 843-849. [CrossRef] [PubMed]

33. Cortellini, A.; Cannita, K.; Parisi, A.; Lanfiuti Baldi, P.; Venditti, O.; D’Orazio, C.; Dal Mas, A.; Calvisi, G.; Giordano, A.V.; Vicentini, V.; et al. Weekly alternate intensive regimen FIrB/FOx in metastatic colorectal cancer patients: An update from clinical practice. Oncol. Targets Ther. 2019, 12, 2159-2170. [CrossRef]

34. Paulson, A.S.; Hess, L.M.; Liepa, A.M.; Cui, Z.L.; Aguilar, K.M.; Clark, J.; Schelman, W. Ramucirumab for the treatment of patients with gastric or gastroesophageal junction cancer in community oncology practices. Gastric Cancer 2018, 21, 831-844. [CrossRef]

35. Parisi, A.; Cortellini, A.; Roberto, M.; Venditti, O.; Santini, D.; Dell'Aquila, E.; Stellato, M.; Marchetti, P.; Occhipinti, M.A.; Zoratto, F.; et al. Weight loss and body mass index in advanced gastric cancer patients treated with second-line ramucirumab: A real-life multicentre study. J. Cancer Res. Clin. Oncol. 2019, 145, PMID: 31280347. 2365-2373. [CrossRef] [PubMed]

36. Thuss-Patience, P.C.; Kretzschmar, A.; Bichev, D.; Deist, T.; Hinke, A.; Breithaupt, K.; Dogan, Y.; Gebauer, B.; Schumacher, G.; Reichardt, P. Survival advantage for irinotecan versus best supportive care as second-line chemotherapy in gastric cancer-a randomised phase III study of the Arbeitsgemeinschaft Internistische Onkologie (AIO). Eur. J. Cancer 2011, 47, 2306-2314. [CrossRef]

37. Kang, J.H.; Lee, S.I.; Lim, D.H.; Park, K.W.; Oh, S.Y.; Kwon, H.C.; Hwang, I.G.; Lee, S.C.; Nam, E.; Shin, D.B.; et al. Salvage chemotherapy for pretreated gastric cancer: A randomized phase III trial comparing chemotherapy plus best supportive care with best supportive care alone. J. Clin. Oncol. 2012, 30, 1513-1518. [CrossRef] [PubMed]

38. Ford, H.E.; Marshall, A.; Bridgewater, J.A.; Janowitz, T.; Coxon, F.Y.; Wadsley, J.; Mansoor, W.; Fyfe, D.; Madhusudan, S.; Middleton, G.W.; et al. Docetaxel versus active symptom control for refractory oesophagogastric adenocarcinoma (COUGAR-02): An open-label, phase 3 randomised controlled trial. Lancet Oncol. 2014, 15, 78-86. [CrossRef]

39. Ter Veer, E.; Haj Mohammad, N.; van Valkenhoef, G.; Ngai, L.L.; Mali, R.M.; van Oijen, M.G.; van Laarhoven, H.W. Second- and third-line systemic therapy in patients with advanced esophagogastric cancer: A systematic review of the literature. Cancer Metastasis Rev. 2016, 35, 439-456. [CrossRef]

40. Kang, Y.K.; Kang, W.K.; Di Bartolomeo, M.; Chau, I.; Yoon, H.H.; Cascinu, S.; Ryu, M.H.; Kim, J.G.; Lee, K.W.; Oh, S.C.; et al. Randomized phase III ANGEL study of rivoceranib (apatinib) + best supportive care (BSC) vs placebo + BSC in patients with advanced/metastatic gastric cancer who failed 2 prior chemotherapy regimens. Ann. Oncol. 2019, 30, v877-v878. [CrossRef]

41. Fuchs, C.S.; Doi, T.; Jang, R.W.; Muro, K.; Satoh, T.; Machado, M.; Sun, W.; Jalal, S.I.; Shah, M.A.; Metges, J.P.; et al. Safety and efficacy of pembrolizumab monotherapy in patients with previously treated advanced gastric and gastroesophageal junction cancer: Phase 2 clinical KEYNOTE-059 trial. JAMA Oncol. 2018, 4, e180013. [CrossRef] [PubMed]

42. Hecht, J.R.; Bang, Y.J.; Qin, S.K.; Chung, H.C.; Xu, J.M.; Park, J.O.; Jeziorski, K.; Shparyk, Y.; Hoff, P.M.; Sobrero, A.; et al. Lapatinib in combination with capecitabine plus oxaliplatin in human epidermal growth factor receptor 2-positive advanced or metastatic gastric, esophageal, or gastroesophageal adenocarcinoma: TRIO-013/LOGiC-a randomized phase III trial. J. Clin. Oncol. 2016, 34, 443-451. [CrossRef] [PubMed]

43. Satoh, T.; Xu, R.H.; Chung, H.C.; Sun, G.P.; Doi, T.; Xu, J.M.; Tsuji, A.; Omuro, Y.; Li, J.; Wang, J.W.; et al. Lapatinib plus paclitaxel versus paclitaxel alone in the second-line treatment of HER2-amplified advanced gastric cancer in Asian populations: TyTAN-A randomized, phase III study. J. Clin. Oncol. 2014, 32, 2039-2049. [CrossRef] 
44. Thuss-Patience, P.C.; Shah, M.A.; Ohtsu, A.; Van Cutsem, E.; Ajani, J.A.; Castro, H.; Mansoor, W.; Chung, H.C.; Bodoky, G.; Shitara, K.; et al. Trastuzumab emtansine versus taxane use for previously treated HER2-positive locally advanced or metastatic gastric or gastro-oesophageal junction adenocarcinoma (GATSBY): An international randomised, open-label, adaptive, phase 2/3 study. Lancet Oncol. 2017, 18, 640-653. [CrossRef]

45. Tabernero, J.; Hoff, P.M.; Shen, L.; Ohtsu, A.; Shah, M.A.; Cheng, K.; Song, C.; Wu, H.; Eng-Wong, J.; Kim, K.; et al. Pertuzumab plus trastuzumab and chemotherapy for HER2-positive metastatic gastric or gastro-oesophageal junction cancer (JACOB): Final analysis of a double-blind, randomised, placebo-controlled phase 3 study. Lancet Oncol. 2018, 19, 1372-1384. [CrossRef]

46. Lordick, F.; Kang, Y.K.; Chung, H.C.; Salman, P.; Oh, S.C.; Bodoky, G.; Kurteva, G.; Volovat, C.; Moiseyenko, V.M.; Gorbunova, V.; et al. Arbeitsgemeinschaft internistische onkologie, EXPAND investigators. Capecitabine and cisplatin with or without cetuximab for patients with previously untreated advanced gastric cancer (EXPAND): A randomised, open label phase 3 trial. Lancet Oncol. 2013, 14, 490-499. [CrossRef]

47. Waddell, T.; Chau, I.; Cunningham, D.; Gonzalez, D.; Okines, A.F.; Okines, C.; Wotherspoon, A.; Saffery, C.; Middleton, G.; Wadsley, J.; et al. Epirubicin, oxaliplatin, and capecitabine with or without panitumumab for patients with previously untreated advanced oesophagogastric cancer (REAL3): A randomised, open-label phase 3 trial. Lancet Oncol. 2013, 14, 481-489. [CrossRef]

48. Catenacci, D.V.T.; Tebbutt, N.C.; Davidenko, I.; Murad, A.M.; Al-Batran, S.E.; Ilson, D.H.; Tjulandin, S.; Gotovkin, E.; Karaszewska, B.; Bondarenko, I.; et al. Rilotumumab plus epirubicin, cisplatin, and capecitabine as first-line therapy in advanced MET-positive gastric or gastro-oesophageal junction cancer (RILOMET-1): A randomised, double-blind, placebo-controlled, phase 3 trial. Lancet Oncol. 2017, 18, 146782. [CrossRef]

49. Shah, M.A.; Bang, Y.J.; Lordick, F.; Alsina, M.; Chen, M.; Hack, S.P.; Bruey, J.M.; Smith, D.; McCaffery, I.; Shames, D.S.; et al. Effect of fluorouracil, leucovorin, and oxaliplatin with or without onartuzumab in HER2-negative, MET-positive gastroesophageal adenocarcinoma: The METGastric randomized clinical trial. JAMA Oncol. 2017, 3, 620-627. [CrossRef]

50. Ohtsu, A.; Ajani, J.A.; Bai, Y.X.; Bang, Y.J.; Chung, H.C.; Pan, H.M.; Sahmoud, T.; Shen, L.; Yeh, K.H.; Chin, K.; et al. Everolimus for previously treated advanced gastric cancer: Results of the randomized, double-blind, phase III GRANITE-1 study. J. Clin. Oncol. 2013, 31, 3935-3943. [CrossRef]

51. Al-Batran, S.E.; Riera-Knorrenschild, J.; Pauligk, C.; Goetze, T.O.; Hegewisch-Becker, S.; Seraphin, J.; Thuss-Patience, P.C.; Kopp, H.G.; Dechow, T.N.; Vogel, A.; et al. A randomized, double-blind, multicenter phase III study evaluating paclitaxel with and without RAD001 in patients with gastric cancer who have progressed after therapy with a fluoropyrimidine/platinum-containing regimen (RADPAC). J. Clin. Oncol. 2017, 35, 4. [CrossRef]

52. Shah, M.A.; Shitara, K.; Lordick, F.; Bang, Y.J.; Tebbutt, N.C.; Metges, J.P.; Muro, K.; Shen, L.; Tjulandin, S.; Hays, J.L.; et al. The BRIGHTER trial: A phase 3 randomized double-blind study of napabucasin (NAPA) plus paclitaxel (PTX) versus placebo (PBO) plus PTX in patients (pts) with pretreated advanced gastric and gastroesophageal junction (GEJ) adenocarcinoma. J. Clin. Oncol. 2018, 36, 4010. [CrossRef]

53. Shah, M.A.; Ruiz, E.P.Y.; Bodoky, G.; Starodub, A.; Cunningham, D.; Yip, D.; Wainberg, Z.A.; Bendell, J.C.; Thai, D.; Bhargava, P. Randomized, double-blind, placebo-controlled study to evaluate the efficacy and safety of andecaliximab combined with mFOLFOX6 as first-line treatment in patients with advanced gastric or gastroesophageal junction adenocarcinoma (GAMMA-1). J. Clin. Oncol. 2019, 37, 4. [CrossRef]

54. Bang, Y.J.; Xu, R.H.; Chin, K.; Lee, K.W.; Park, S.H.; Rha, S.Y.; Shen, L.; Qin, S.; Xu, N.; Im, S.A.; et al. Olaparib in combination with paclitaxel in patients with advanced gastric cancer who have progressed following first-line therapy (GOLD): A double-blind, randomised, placebo-controlled, phase 3 trial. Lancet Oncol. 2017, 18, 1637-1651. [CrossRef]

55. Cancer Genome Atlas Research Network. Comprehensive molecular characterization of gastric adenocarcinoma. Nature 2014, 513, 202-209. [CrossRef] [PubMed]

56. Pearson, A.; Smyth, E.; Babina, I.S.; Herrera-Abreu, M.T.; Tarazona, N.; Peckitt, C.; Kilgour, E.; Smith, N.R.; Geh, C.; Rooney, C.; et al. High-Level Clonal FGFR Amplification and Response to FGFR Inhibition in a Translational Clinical Trial. Cancer Discov. 2016, 6, 838-851. [CrossRef] [PubMed]

57. Maron, S.B.; Alpert, L.; Kwak, H.A.; Lomnicki, S.; Chase, L.; Xu, D.; O’Day, E.; Nagy, R.J.; Lanman, R.B.; Cecchi, F.; et al. Targeted therapies for targeted populations: Anti-EGFR treatment for EGFR-amplified gastroesophageal adenocarcinoma. Cancer Discov. 2018, 8, 696-713. [CrossRef] [PubMed] 
58. Fuchs, C.S.; Shitara, K.; Di Bartolomeo, M.; Lonardi, S.; Al-Batran, S.E.; Van Cutsem, E.; Ilson, D.H.; Alsina, M.; Chau, I.; Lacy, J.; et al. Ramucirumab with cisplatin and fluoropyrimidine as first-line therapy in patients with metastatic gastric or junctional adenocarcinoma (RAINFALL): A double-blind, randomised, placebo-controlled, phase 3 trial. Lancet Oncol. 2019, 20, 420-435. [CrossRef]

59. Shen, L.; Li, J.; Xu, J.; Pan, H.; Dai, G.; Qin, S.; Wang, L.; Wang, J.; Yang, Z.; Shu, Y.; et al. Bevacizumab plus capecitabine and cisplatin in Chinese patients with inoperable locally advanced or metastatic gastric or gastroesophageal junction cancer: Randomized, double-blind, phase III study (AVATAR study). Gastric Cancer 2015, 18, 168-176. [CrossRef] [PubMed]

60. Van Cutsem, E.; de Haas, S.; Kang, Y.K.; Ohtsu, A.; Tebbutt, N.C.; Ming Xu, J.; Peng Yong, W.; Langer, B.; Delmar, P.; Scherer, S.J.; et al. Bevacizumab in combination with chemotherapy as first-line therapy in advanced gastric cancer: A biomarker evaluation from the AVAGAST randomized phase III trial. J. Clin. Oncol. 2012, 30, 2119-2127. [CrossRef]

61. Parisi, A.; Cortellini, A.; Cannita, K.; Venditti, O.; Camarda, F.; Calegari, M.A.; Salvatore, L.; Tortora, G.; Rossini, D.; Germani, M.M.; et al. Evaluation of Second-line Anti-VEGF after First-line Anti-EGFR Based Therapy in RAS Wild-Type Metastatic Colorectal Cancer: The Multicenter "SLAVE" Study. Cancers (Basel) 2020, 12, 1259. [CrossRef] [PubMed]

62. Shitara, K.; Bang, Y.J.; Iwasa, S.; Sugimoto, N.; Ryu, M.H.; Sakai, D.; Chung, H.C.; Kawakami, H.; Yabusaki, H.; Lee, J.; et al. Trastuzumab Deruxtecan in Previously Treated HER2-Positive Gastric Cancer. N. Engl. J. Med. 2020, 382, 2419-2430. [CrossRef] [PubMed]

63. Schuler, M.; Al-Batran, S.; Zvirbule, Z.; Manikhas, G.; Lordick, F.; Rusyn, A.; Vinnyk, Y.; Vynnychenko, I.; Fadeeva, N.; Nechaeva, M.; et al. Final results of the FAST study, an international, multicenter, randomized, phase II trial of epirubicin, oxaliplatin, and capecitabine (EOX) with or without the anti-CLDN18.2 antibody IMAB362 as first-line therapy in patients with advanced CLDN18.2+ gastric and gastroesophageal junction (GEJ) adenocarcinoma. Ann. Oncol. 2016, 27, 207-242.

64. Sharma, P.; Allison, J.P. The future of immune checkpoint therapy. Science 2015, 348, 56-61. [CrossRef] [PubMed]

65. Lawrence, M.S.; Stojanov, P.; Polak, P.; Kryukov, G.V.; Cibulskis, K.; Sivachenko, A.; Carter, S.L.; Stewart, C.; Mermel, C.H.; Roberts, S.A.; et al. Mutational heterogeneity in cancer and the search for new cancer-associated genes. Nature 2013, 499, 214-218. [CrossRef]

66. Chen, L.T.; Kang, Y.K.; Satoh, T.; Chao, Y.; Kato, K.; Chung, C.H.; Chen, J.S.; Muro, K.; Kang, W.K.; Oh, S.C.; et al. A phase III study of nivolumab (Nivo) in previously treated advanced gastric or gastric esophageal junction (G/GEJ) cancer (ATTRACTION-2): Three-year update data. J. Clin. Oncol. 2020, 38, abstr 383. [CrossRef]

67. Cortellini, A.; Buti, S.; Agostinelli, V.; Bersanelli, M. A systematic review on the emerging association between the occurrence of immune-related adverse events and clinical outcomes with checkpoint inhibitors in advanced cancer patients. Semin. Oncol. 2019, 46, 362-371. [CrossRef]

68. Janjigian, Y.Y.; Bendell, J.; Calvo, E.; Kim, J.W.; Ascierto, P.A.; Sharma, P.; Ott, P.A.; Peltola, K.; Jaeger, D.; Evans, J.; et al. CheckMate-032 Study: Efficacy and Safety of Nivolumab and Nivolumab Plus Ipilimumab in Patients With Metastatic Esophagogastric Cancer. J. Clin. Oncol. 2018, 36, 2836-2844. [CrossRef]

69. Fuchs, C.S.; Özgüroğlu, M.; Bang, Y.J.; Di Bartolomeo, M.; Mandalà, M.; Ryu, M.H.; Fornaro, L.; Olesinski, T.; Caglevic, C.; Chung, H.C.; et al. Pembrolizumab versus paclitaxel for previously treated patients with PD-L1-positive advanced gastric or gastroesophageal junction cancer (GC): Update from the phase III KEYNOTE-061 trial. J. Clin. Oncol. 2020, 38 (Suppl. 15), 4503.

70. Bang, Y.J.; Ruiz, E.Y.; Van Cutsem, E.; Lee, K.W.; Wyrwicz, L.; Schenker, M.; Alsina, M.; Ryu, M.H.; Chung, H.C.; Evesque, L.; et al. Phase III randomised trial of avelumab versus physician's choice of chemotherapy as third-line treatment of patients with advanced gastric or gastro-oesophageal junction cancer: Primary analysis of JAVELIN Gastric 300. Ann. Oncol. 2018, 29, 2052-2060. [CrossRef] 
71. Moehler, M.H.; Dvorkin, M.; Ozguroglu, M.; Ryu, M.H.; Muntean, A.S.; Lonardi, S.; Nechaeva, M.; Bragagnoli, A.S.C.; Coskun, H.S.; Gracián, A.C.; et al. Results of the JAVELIN Gastric 100 phase 3 trial: Avelumab maintenance following first-line (1L) chemotherapy (CTx) vs continuation of CTx for HER2-advanced gastric or gastroesophageal junction cancer (GC/GEJC). J. Clin. Oncol. 2020, 38, 278. [CrossRef]

72. Murugaesu, N.; Wilson, G.A.; Birkbak, N.J.; Watkins, T.; McGranahan, N.; Kumar, S.; Abbassi-Ghadi, N.; Salm, M.; Mitter, R.; Horswell, S.; et al. Tracking the genomic evolution of esophageal adenocarcinoma through neoadjuvant chemotherapy. Cancer Discov. 2015, 5, 821-883. [CrossRef] [PubMed]

73. Tabernero, J.; Van Cutsem, E.; Bang, Y.J.; Fuchs, C.S.; Wyrwicz, L.; Lee, K.W.; Kudaba, I.; Garrido, M.; Chung, H.C.; Castro Salguero, H.R.; et al. Pembrolizumab with or without chemotherapy versus chemotherapy for advanced gastric or gastroesophageal junction (G/GEJ) adenocarcinoma: The phase III KEYNOTE-062 study. J. Clin. Oncol. 2019, 37 (Suppl. 18), LBA4007. [CrossRef]

74. Shitara, K.; Van Cutsem, E.; Bang, Y.J.; Fuchs, C.S.; Wyrwicz, L.; Lee, K.W.; Kudaba, I.; Garrido, M.; Cheol Chung, H.; Castro, H.R.; et al. Pembrolizumab with or without chemotherapy vs chemotherapy in patients with advanced G/GEJ cancer (GC) including outcomes according to Microsatellite Instability-High (MSI-H) status in KEYNOTE-062. Ann. Oncol. 2019, 30, v878-v879. [CrossRef]

75. Kim, S.T.; Cristescu, R.; Bass, A.J.; Kim, K.M.; Odegaard, J.I.; Kim, K.; Liu, X.Q.; Sher, X.; Jung, H.; Lee, M.; et al. Comprehensive molecular characterization of clinical responses to PD-1 inhibition in metastatic gastric cancer. Nat. Med. 2018, 24, 1449-1588. [CrossRef]

76. Zitvogel, L.; Ma, Y.; Raoult, D.; Kroemer, G.; Gajewski, T.F. The microbiome in cancer immunotherapy: Diagnostic tools and therapeutic strategies. Science 2018, 359, 1366-1370. [CrossRef]

77. Khan, K.A.; Kerbel, R.S. Improving immunotherapy outcomes with anti-angiogenic treatments and vice versa. Nat. Rev. Clin. Oncol. 2018, 15, 310-324. [CrossRef]

78. Schmittnaegel, M.; De Palma, M. Reprogramming Tumor Blood Vessels for Enhancing Immunotherapy. Trends Cancer 2017, 3, 809-812. [CrossRef]

79. Hara, H.; Shoji, H.; Takahari, D.; Esaki, T.; Machida, N.; Nagashima, K.; Aoki, K.; Honda, K.; Miyamoto, T.; Boku, N.; et al. Phase I/II study of ramucirumab plus nivolumab in patients in second-line treatment for advanced gastric adenocarcinoma (NivoRam study). J. Clin. Oncol. 2019, 37, 129. [CrossRef]

80. Chau, I.; Bendell, J.; Soriano, A.; Arkenau, H.; Cultrera, J.; Santana-Davila, R.; Calvo, E.; Tourneau, C.L.; Zender, L.; Mi, G.; et al. Safety and antitumor activity from the phase Ib study of ramucirumab plus pembrolizumab in treatment-naive advanced gastric or gastroesophageal junction (G/GEJ) adenocarcinoma (JVDF). Ann. Oncol. 2019, 30, iv122. [CrossRef]

81. Fukuoka, S.; Hara, H.; Takahashi, N.; Kojima, T.; Kawazoe, A.; Asayama, M.; Yoshii, T.; Kotani, D.; Tamura, H.; Mikamoto, Y.; et al. Regorafenib plus nivolumab in patients with advanced gastric (GC) or colorectal cancer (CRC): An open-label, dose-finding, and dose-expansion phase $1 \mathrm{~b}$ trial (REGONIVO, EPOC1603). J. Clin. Oncol. 2019, 37, 2522. [CrossRef]

82. Kawazoe, A.; Fukuoka, S.; Nakamura, Y.; Kuboki, Y.; Wakabayashi, M.; Nomura, S.; Mikamoto, Y.; Shima, H.; Fujishiro, N.; Higuchi, T.; et al. Lenvatinib plus pembrolizumab in patients with advanced gastric cancer in the first-line or second-line setting (EPOC1706): An open-label, single-arm, phase 2 trial. Lancet Oncol. 2020. [CrossRef]

83. Varadan, V.; Gilmore, H.; Miskimen, K.L.S.; Tuck, D.; Parsai, S.; Awadallah, A.; Krop, I.E.; Winer, E.P.; Bossuyt, V.; Somlo, G.; et al. Immune signatures following single dose trastuzumab predict pathologic response to preoperative trastuzumab and chemotherapy in HER2-positive early breast cancer. Clin. Cancer Res. 2016, 22, 3249-3259. [CrossRef] [PubMed]

84. Janjigian, Y.; Maron, S.B.; Chatila, W.K.; Millang, B.; Chavan, S.S.; Alterman, C.; Chou, J.F.; Segal, M.F.; Simmons, M.Z.; Momtaz, P.; et al. First-line pembrolizumab and trastuzumab in HER2-positive oesophageal, gastric, or gastro-oesophageal junction cancer: An open-label, single-arm, phase 2 trial. Lancet Oncol. 2020, 21, 821-831. [CrossRef]

85. Al-Batran, S.E.; Homann, N.; Pauligk, C.; Goetze, T.O.; Meiler, J.; Kasper, S.; Kopp, H.G.; Mayer, F.; Haag, G.M.; Luley, K.; et al. Perioperative chemotherapy with fluorouracil plus leucovorin, oxaliplatin, and docetaxel versus fluorouracil or capecitabine plus cisplatin and epirubicin for locally advanced, resectable gastric or gastro-oesophageal junction adenocarcinoma (FLOT4): A randomised, phase 2/3 trial. Lancet 2019, 393, 1948-1957. [CrossRef] [PubMed] 
86. Noh, S.H.; Park, S.R.; Yang, H.K.; Chung, H.C.; Chung, I.J.; Kim, S.W.; Kim, H.H.; Choi, J.H.; Kim, H.K.; $\mathrm{Yu}, \mathrm{W}$; ; et al. Adjuvant capecitabine plus oxaliplatin for gastric cancer after D2 gastrectomy (CLASSIC): 5-year follow-up of an openlabel, randomised phase 3 trial. Lancet Oncol. 2014, 15, 1389-1396. [CrossRef]

87. Qiu, M.Z.; Shi, S.M.; Chen, Z.H.; Yu, H.E.; Sheng, H.; Jin, Y.; Wang, D.S.; Wang, F.H.; Li, Y.H.; Xie, D.; et al. Frequency and clinicopathological features of metastasis to liver, lung, bone, and brain from gastric cancer: A SEER-based study. Cancer Med. 2018, 7, 3662-3672. [CrossRef]

88. Jacquet, P.; Sugarbaker, P.H. Peritoneal-plasma barrier. Cancer Treat Res. 1996, 82, 53-63.

89. Thomassen, I.; van Gestel, Y.R.; van Ramshorst, B.; Luyer, M.D.; Bosscha, K.; Nienhuijs, S.W.; Lemmens, V.E.; de Hingh, I. Peritoneal carcinomatosis of gastric origin: A population-based study on incidence, survival and risk factors. Int. J. Cancer 2014, 134, 622-628. [CrossRef]

90. Speyer, J.L.; Sugarbaker, P.H.; Collins, J.M.; Dedrick, R.L.; Klecker, R.W., Jr.; Myers, C.E. Portal levels and hepatic clearance of 5-fluorouracil after intraperitoneal administration in humans. Cancer Res. 1981, 41, 1916-1922.

91. Overgaard, J. Effect of hyperthermia on malignant cells in vivo. A review and a hypothesis. Cancer 1977, 39, 2637-2646. [CrossRef]

92. de Bree, E.; Tsiftsis, D.D. Principles of perioperative intraperitoneal chemotherapy for peritoneal carcinomatosis. Recent Results Cancer Res. 2007, 169, 39-51. [PubMed]

93. Kuijpers, A.M.; Aalbers, A.G.; Nienhuijs, S.W.; de Hingh, I.H.; Wiezer, M.J.; van Ramshorst, B.; van Ginkel, R.J.; Havenga, K.; Heemsbergen, W.D.; Hauptmann, M.; et al. Implementation of a standardized HIPEC protocol improves outcome for peritoneal malignancy. World J. Surg. 2015, 39, 453-460. [CrossRef] [PubMed]

94. Alyami, M.; HuÜbner, M.; Grass, F.; Bakrin, N.; Villeneuve, L.; Laplace, N.; Passot, G.; Glehen, O.; Kepenekian, V. Pressurised intraperitoneal aerosol chemotherapy: Rationale, evidence, and potential indications. Lancet Oncol. 2019, 20, e368-e377. [CrossRef]

95. Nadiradze, G.; Giger-Pabst, U.; Zieren, J.; Strumberg, D.; Solass, W.; Reymond, M.A. Pressurized intraperitoneal aerosol chemotherapy (PIPAC) with low-dose cisplatin and doxorubicin in gastric peritoneal metastasis. J. Gastrointest. Surg. 2016, 20, 367-373. [CrossRef]

96. Khomyakov, V.; Ryabov, A.; Ivanov, A.; Bolotina, L.; Utkina, A.; Volchenko, N.; . \& Kaprin, A. Bidirectional chemotherapy in gastric cancer with peritoneal metastasis combining intravenous XELOX with intraperitoneal chemotherapy with low-dose cisplatin and Doxorubicin administered as a pressurized aerosol: An open-label, Phase-2 study (PIPAC-GA2). Pleura Peritoneum 2016, 1, 159-166. [CrossRef]

97. Struller, F.; Horvath, P.; Solass, W.; Weinreich, F.J.; Strumberg, D.; Kokkalis, M.K.; Fischer, I.; Meisner, C.; Königsrainer, A.; Reymond, M. Pressurized intraperitoneal aerosol chemotherapy with low-dose cisplatin and doxorubicin (PIPAC C/D) in patients with gastric cancer and peritoneal metastasis: A phase II study. Ther. Adv. Med. Oncol. 2019, 11, 1758835919846402. [CrossRef]

98. Cruz-Jentoft, A.J.; Baeyens, J.P.; Bauer, J.M.; Boirie, Y.; Cederholm, T.; Landi, F.; Martin, F.C.; Michel, J.P.; Rolland, Y.; Schneider, S.M. Sarcopenia: European consensus on definition and diagnosis: Report of the European Working Group on Sarcopenia in Older People. Age Ageing 2010, 39, 412-423. [CrossRef]

99. Ryall, J.G.; Schertzer, J.D.; Lynch, G.S. Cellular and molecular mechanisms underlying age-related skeletal muscle wasting and weakness. Biogerontology 2008, 9, 213-228. [CrossRef]

100. Skipworth, R.J.E.; Stewart, G.D.; Dejong, C.H.C.; Preston, T.; Fearon, K.C.H. Pathophysiology of cancer cachexia: Much more than host-tumour interaction? Clin. Nutr. 2007, 26, 667-676. [CrossRef]

101. Ezeoke, C.C.; Morley, J.E. Pathophysiology of anorexia in the cancer cachexia syndrome. J. Cachexia Sarcopenia Muscle 2015, 6, 287-302. [CrossRef] [PubMed]

102. Zhuang, C.-L.; Huang, D.-D.; Pang, W.-Y.; Zhou, C.-J.; Wang, S.-L.; Lou, N.; Ma, L.L.; Yu, Z.; Shen, X. Sarcopenia is an independent predictor of severe postoperative complications and long-term survival after radical gastrectomy for gastric cancer: Analysis from a large-scale cohort. Medicine 2016, 95, e3164. [CrossRef] [PubMed]

103. Yamaoka, Y.; Fujitani, K.; Tsujinaka, T.; Yamamoto, K.; Hirao, M.; Sekimoto, M. Skeletal muscle loss after total gastrectomy, exacerbated by adjuvant chemotherapy. Gastric Cancer. 2015, 18, 382-389. [CrossRef] [PubMed]

104. Vellas, B.; Guigoz, Y.; Garry, P.J.; Nourhashemi, F.; Bennahum, D.; Lauque, S.; Albarede, J.L. The mini nutritional assessment (MNA) and its use in grading the nutritional state of elderly patients. Nutrition 1999, 15, 116-122. [CrossRef] 
105. Cortellini, A.; Porzio, G.; Cofini, V.; Necozione, S.; Parisi, A.; Peris, F.; Ravoni, G.; Spinelli, G.; Masel, E.K.; Berghoff, A.S.; et al. The PERSONS score: A new tool for cancer patients' symptom assessment in simultaneous care and home care settings. Palliat. Support. Care 2020, 18, 33-38. [CrossRef]

106. Cortellini, A.; Porzio, G.; Masel, E.K.; Berghoff, A.S.; Knotzer, B.; Parisi, A.; Pavese, F.; Ficorella, C.; Verna, L. The PERSONS score for symptoms assessment in simultaneous care setting: A pilot study. Palliat. Support. Care 2019, 17, 82-86. [CrossRef]

107. Deans, D.A.C.; Tan, B.H.; Wigmore, S.J.; Ross, J.A.; de Beaux, A.C.; Paterson-Brown, S.; Fearon, K.C. The influence of systemic inflammation, dietary intake and stage of disease on rate of weight loss in patients with gastro-oesophageal cancer. Br. J. Cancer 2009, 100, 63-69. [CrossRef]

108. Cortellini, A.; Palumbo, P.; Porzio, G.; Verna, L.; Giordano, A.V.; Masciocchi, C.; Parisi, A.; Cannita, K.; Ficorella, C.; Bozzetti, F. Single-institution study of correlations between skeletal muscle mass, its density, and clinical outcomes in non-small cell lung cancer patients treated with first-line chemotherapy. Thorac. Cancer 2018, 9, 1623-1630. [CrossRef]

109. Cortellini, A.; Verna, L.; Porzio, G.; Bozzetti, F.; Palumbo, P.; Masciocchi, C.; Cannita, K.; Parisi, A.; Brocco, D.; Tinari, N.; et al. Predictive value of skeletal muscle mass for immunotherapy with nivolumab in non-small cell lung cancer patients: A "hypothesis-generator" preliminary report. Thorac. Cancer 2019, 10, 347-351. [CrossRef]

110. Huang, D.-D.; Zhou, C.-J.; Wang, S.-L.; Mao, S.-T.; Zhou, X.-Y.; Lou, N.; Zhang, Z.; Yu, Z.; Shen, X.; Zhuang, C.L. Impact of different sarcopenia stages on the postoperative outcomes after radical gastrectomy for gastric cancer. Surgery 2017, 161, 680-693. [CrossRef]

111. Caccialanza, R.; Pedrazzoli, P.; Cereda, E.; Gavazzi, C.; Pinto, C.; Paccagnella, A.; Beretta, G.D.; Nardi, M.; Laviano, A.; Zagonel, V. Nutritional support in cancer patients: A position paper from the Italian Society of Medical Oncology (AIOM) and the Italian Society of Artificial Nutrition and Metabolism (SINPE). J. Cancer 2016, 7, 131-135. [CrossRef] [PubMed]

112. Lopez, A.P.; Roqué i Figuls, M.; Cuchi, G.U.; Berenstein, E.G.; Pasies, B.A.; Alegre, M.B.; Herdman, M. Systematic review of megestrol acetate in the treatment of anorexia-cachexia syndrome. J. Pain Symptom Manag. 2004, 27, 360-369. [CrossRef] [PubMed]

113. Greig, C.A.; Johns, N.; Gray, C.; MacDonald, A.; Stephens, N.A.; Skipworth, R.J.E.; Fallon, M.; Wall, L.; Fox, G.M.; Fearon, K.C. Phase I/II trial of formoterol fumarate combined with megestrol acetate in cachectic patients with advanced malignancy. Support. Care Cancer 2014, 22, 1269-1275. [CrossRef] [PubMed]

114. Ross, D.D.; Alexander, C.S. Management of common symptoms in terminally ill patients: Part I. Fatigue, anorexia, cachexia, nausea and vomiting. Am. Fam. Physician 2001, 64, 807-814. [PubMed] 